\title{
Neolithic geoarchaeology at Penedo dos Mouros Rockshelter: Mid-Holocene site formation, diagenesis and human activity at the foothills of Serra da Estrela (Portugal)
}

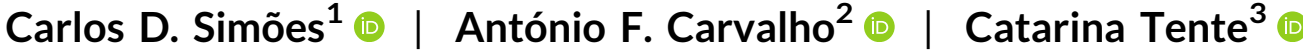

${ }^{1}$ Interdisciplinary Center for Archaeology and Evolution of Human Behaviour (ICArEHB), Faculty of Human and Social Sciences,

Universidade do Algarve, Faro, Portugal

${ }^{2}$ Department of Arts and Humanities, Centro de Estudos de Arqueologia, Artes e Ciências do Património (CEAACP), Faculty of Human and Social Sciences, Universidade do Algarve, Faro, Portugal

${ }^{3}$ Department of History, Institute of Medieval Studies (IEM), Universidade Nova de Lisboa, Lisbon, Portugal

\section{Correspondence}

Carlos D. Simões, Interdisciplinary Center for Archaeology and the Evolution of Human Behaviour (ICArEHB), Universidade do Algarve, Campus de Gambelas, 8005-139 Faro, Portugal.

Email: cduarte.as@gmail.com

Scientific editing by Paul Goldberg

Funding information

Fundação para a Ciência e a Tecnologia

\begin{abstract}
The Neolithic occupation of Penedo dos Mouros in the foothills of Serra da Estrela, Portugal's highest mountain, dates to the 5th to 4th millennia cal B.C. The site's faunal assemblage is extremely rare in the regional prehistoric archaeological record, due to the acidity of the granitic geology. This underlines Penedo dos Mouros importance as a reference site for understanding early pastoralism in the region. Due to the insufficient survival of bone collagen for radiocarbon dating and the homogeneity of the stratigraphy, where most visible contacts are due to postdepositional processes, we chose micromorphology to address the reasons behind the bone preservation and to assess the stratigraphic integrity of the prehistoric deposit. Reworking of eroding saprolitic soils was a major factor in the sediment accumulation, with remains of short human occupation events. Possible evidence for clearance fires linked to the first occurrences of pastoralism practised in the region, creating open spaces for grazing, was identified. Post-depositional carbonate cementation derived from ashes, identifiable at the microscopic scale, enabled bone preservation. Carbonate and spodic-like features document water saturation once the sedimentation ceased. This sedimentary dynamic has broader geomorphological implications, such as an inferred post-Neolithic incision of the stream valley adjacent to the site.
\end{abstract}

\section{KEYWORDS}

ash and bone preservation, clearance, colluvial deposit, micromorphology, neolithic, soil erosion

\section{INTRODUCTION}

Serra da Estrela (in Beira Alta province), is the highest summit in continental Portugal, culminating at $1,993 \mathrm{~m}$ above sea level (hereafter, a.s.l.; Figure 1a,b). In oral tradition and ancient written sources, this orographic feature has played an important symbolic role in the origins of Portugal, as presumed refuge territory of the Lusitanians during their wars against the Roman invaders in the 2 nd century B.C. Therefore, it is not surprising that the scientific reconnaissance of ancient settlement in the area was one of the major foci from the onset of archaeological research in the country. Indeed, scientifically based references to dolmens were published as early as the mid-19th century by Costa (1868, pp. 86-87), in the first synthesis on Portuguese megalithism. Soon after, the "Scientific Expedition to Serra da Estrela" was carried out by the Lisbon Geographical Society in 1881 and amongst its aims was the discovery and inventory of dolmens. It succeeded at obtaining detailed descriptions of some megalithic monuments of the region (Sarmento, 1983). However, with the exception of a few finds discovered in 1997 near the Vale do Rossim Dam (Cardoso \& González, 2002) at 1,430m a.s.l., all the prehistoric sites discovered so far are located in the mountain's foothills, below $700 \mathrm{~m}$ a.s.l. Among these are open air sites, 

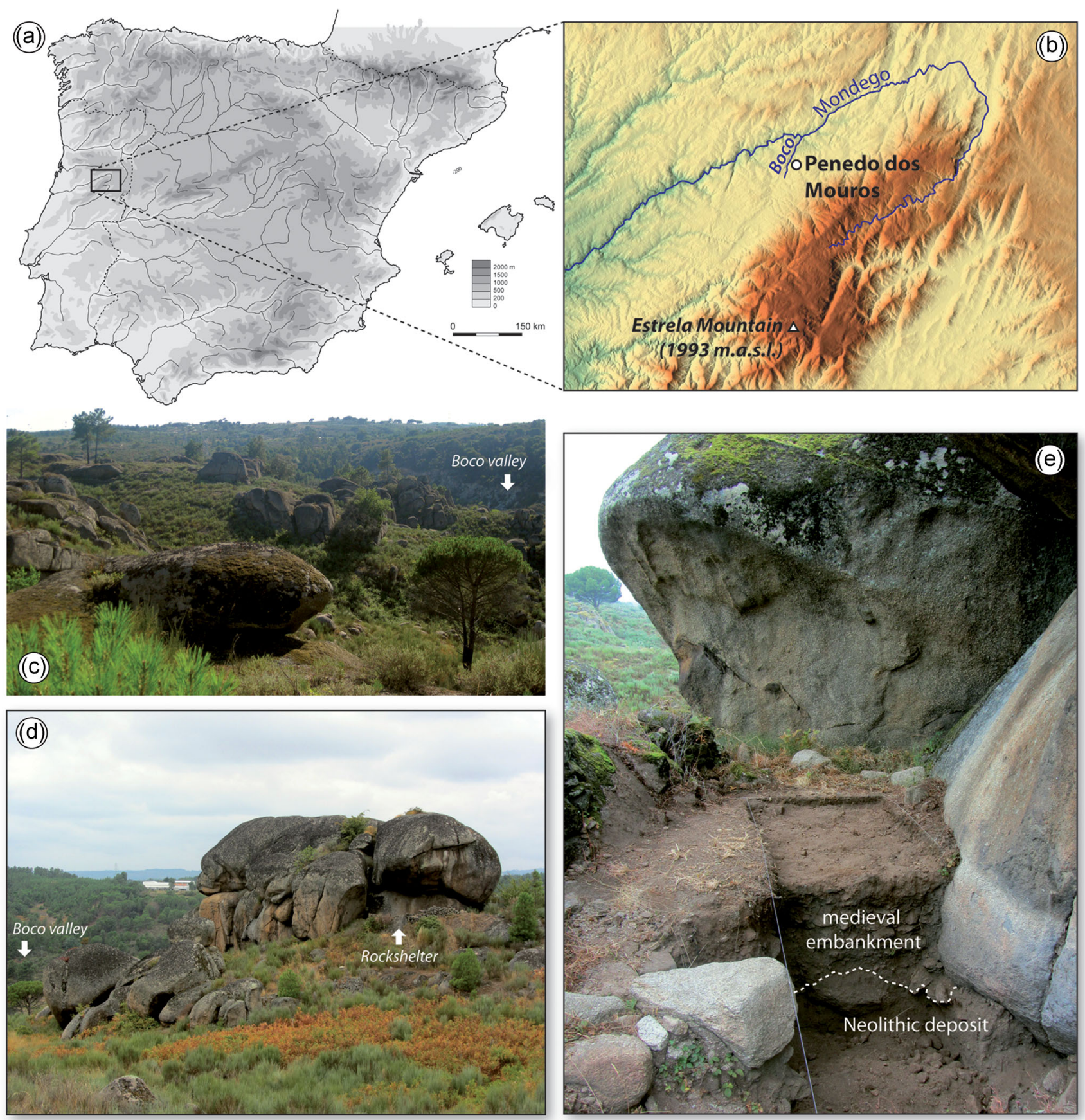

FIGURE 1 Location and surroundings of Penedos dos Mouros. (a) Geographical location of the region of Estrela Mountain in the Iberian Peninsula (rectangle enlarged in (b)). (b) Penedo dos Mouros in the Boco Valley, between the Estrela Mountain and the Mondego River. (c) View from the site towards southwest, note the levelled platforms cut by granitic outcrops and the Boco valley in the background. (d) View of the monumental tor of Penedo dos Mouros from the southeast, indicating the position of the rockshelter and the Boco Valley, the slope and the seasonal rill are indicated by the reddish vegetation. (e) Aspect of the rockshelter surface and Test 1, which is $2 \mathrm{~m}$ wide (see Figure $2 \mathrm{a}$ ), the contact between the medieval embankment and the Neolithic deposits is marked with a dashed line [Color figure can be viewed at wileyonlinelibrary.com]

rockshelters, walled enclosures and dolmens distributed across the mountain's western and north-western flanks, and the adjacent Mondego River valley (for syntheses, see Senna-Martinez \& Ventura, 2008; Valera, 2005).

Ethnographic and historic accounts emphasize the importance of montane resources for local traditional economies, especially a type of vertical transhumance system for sheep and goat that disappeared in the 20th century. One of the key-questions in the study of this practice has been to determine its origins and how it evolved. Recent strategies are well known and documented (Ribeiro, 1941), and in the last decade, medieval practices have received more important archaeological and zooarchaeological attention (Fernández-Mier \& 
Tente, 2018). However, early forms of pastoralism have only been tentatively assumed as a logical progression given the evidence for Neolithic subsistence strategies in Portugal, especially within the central-southern region-see discussion in Carvalho (2018) and Valente and Carvalho (2014).

There are two limitations-methodological and taphonomic-that have prevented the development of a clear picture of the Neolithic stock-keeping practices in Serra da Estrela. The former is the scarcity of environmental reconstructions due to lack of high-resolution studies. At present, pollen analysis from mountain lakes, such as Charco da Candieira and Lagoa Comprida at 1,400 and 1,600 m a.s.l., respectively, are the only data sets that provide insight into the climate and ecological conditions throughout the Holocene. These data sets record oscillations between periods of warmer and drier conditions and those of cooler and wet conditions, in an overall trend towards an increased oceanic climate during the mid-Holocene. Several deforestation episodes and vegetal replacement processes presumably human-induced, such as grazing and cultivation, have been identified (Van den Brink \& Janssen, 1985; Van der Knaap \& van Leeuwen, 1995, 1997). From c. 4,500 cal B.C., onwards during the transition from the Early to the Middle Neolithic, the authors interpret that changes in the pollen record are mostly influenced by anthropogenic impact rather than the result of climatic changes (Van der Knaap \& van Leeuwen, 1995).

These pollen sequences have their limitations. First, they are only representative of high-altitude locations and can be used only by extrapolation as proxies to deduce low altitude Mid-Holocene vegetation cover. Second, absolute chronologies, based on radiocarbon dating of charcoal from these pollen cores, are too broad in temporal scope and thus are barely usable to pinpoint precise (pre-)historical events. For example, Van der Knaap and van Leeuwen (1995, p. 186) claim that "[t]he low but significant percentages of Cerealia $(<1 \%)$ in zones B3b to B5a [at Charco da Candieira] (c. 7,655-6,570 BP) possibly reflect either a period of agriculture in the lowlands or a period of human-induced expansion of steppe grasses" but, as highlighted elsewhere (Carvalho, 2012), this is before any evidence for farming in the whole western half of the Iberian Peninsula.

The taphonomic limitation refers to the acidity of granite soils that predominate on the mountain and in its surroundings (Figure 1c). This factor has prevented the preservation of osteological assemblages in archaeological contexts, especially in the older ones, due to diagenetic processes. This was not the case, however, at the Penedo dos Mouros rockshelter (Figure 1d,e), in the municipality of Gouveia, where a small and poorly preserved assemblage (including sheep remains) was found but whose archaeological attribution to the Early Neolithic makes it a unique find with far-reaching consequences to the study of the earliest evidence of pastoralism within the region.

The micromorphological study presented here of the Neolithic deposit at the Penedo dos Mouros Rockshelter addresses both stratigraphic and preservation issues. A description of the stratigraphic sequence observed in Test 1 is summarized in Table 1 . The material culture from the site forms a coherent assemblage whereas its vertical distribution throughout the deposit appears to be a testimony of different episodes of human occupation at the site during the late 5th and beginning of the 4th millennia B.C. (Carvalho, Pereira, Duarte, \& Tente, 2017). However, overall the prehistoric deposit is composed of unsorted coarse sand with layer 9 being the most outstanding stratigraphic feature identified in Test 1 (Figure $2 a-d$ ). Layer 9 is an irregular dark hardpan with ferruginous texture, ranging from 1 to $20 \mathrm{~cm}$ thick (Figures $2 \mathrm{~b}$ and $2 \mathrm{e}$ and $3 a, b$ ). In this study, we aim to use micromorphology to understand the nature and formation of the hardpan, since it creates a differentiating factor in the Prehistoric deposit, not necessarily corresponding to a depositional contact (Mallol \& Mentzer, 2017). Furthermore, this feature influenced the character of archaeological material within it. Bones, for example, exhibited hardened coatings of the same ferruginous nature and were substantially heavier than normal. The effects of this diagenetic process on the preservation of organic materials at the site was remarkable. Therefore, the micromorphological analysis is also intended to understand the contextual conditions of the Neolithic remains.

Despite several attempts at radiocarbon dating the Neolithic occupation using bone samples, it proved impossible due to low amounts of well-preserved collagen (Table 2). Only a sheep metacarpal from the bottom of layer 11 provided a result (Wk-35998: 3,559 \pm 27 BP; ca. 1,800 cal B.C.), which was incompatible with any archaeological evidence observed at the site. Therefore, an accurate assessment is necessary of the context with archaeological remains. Moreover, it is well established that organic materials of archaeological interest, such as bone, do not survive well in acidic environments (Berna, Matthews, \& Weiner, 2004, Weiner, 2010). Since the Penedo dos Mouros case contradicts such a priori expectations, it is also fundamental to assess the geochemical conditions to provide context and the correct interpretation of the exhumed organic materials (Goldberg \& Berna, 2010; Karkanas, 2010).

\section{1 | Site background}

Penedo dos Mouros (40 $31^{\prime} 41.63^{\prime \prime}$ N.; $7^{\circ} 37^{\prime} 47.50^{\prime \prime}$ W.) is a midslope platform, at $436 \mathrm{~m}$ a.s.l., over the Boco valley, which belongs to the basin of the upper Mondego River (Figure 1b). This is one of several levelled platforms breaking the slope profile (Figure 1c), a major feature of the regional geomorphology characterized by granitic tors and boulder piles.

Angelucci, Tente, and Martins (2004) conducted a geomorphological analysis of the site surroundings centred on the contextualization of the Medieval occupation. Systematic excavations carried out since the end of the 1990s revealed segments of a walled perimeter and palisade (ca. 0.6 ha) built between the boulders to protect the settlement. Inside, different types of evidence, such as remains of burnt tree trunks, steps and notches carved in a monumental tor to support beams, indicated the existence of a two-story wooden building, which collapsed after a fire in the 10th century. The 
TABLE 1 Penedo dos Mouros rockshelter: Brief field description of stratigraphic units and chronological attribution

\begin{tabular}{|c|c|c|}
\hline & Unit & Field description \\
\hline \multirow[t]{7}{*}{ Test 1} & 0 & $\begin{array}{l}\text { Loose, powdery sediments of humus nature, } 5-20 \mathrm{~cm} \text { thick, with light brownish colours. It covers all the } \\
\text { sheltered area. }\end{array}$ \\
\hline & 1 & Brown sediments below [0] filling structure [2]. \\
\hline & 2 & Stone structure of unclear function, located in squares A7-8/B7/B-C8. \\
\hline & 3 & $\begin{array}{l}\text { Brownish layer made of fine-grained sands, scattered charcoal and large granite blocks ( }>50 \mathrm{~cm} \text { ). It is the } \\
\text { Test's thickest layer: } \mathrm{c} \text {. } 70 \mathrm{~cm} \text { in C-D9 profile (see Figure 2) and almost } 1 \mathrm{~m} \text { in the opposite profile, } \\
\text { whereas it top is horizontal. It bears medieval ceramics (pottery and brick fragments) throughout its } \\
\text { thickness without any particular concentration; near the top some modern potsherds were also found. } \\
\text { Its particular micro-topography and archaeological contents indicate this is a deliberate infilling } \\
\text { datable to Medieval times aiming at the flattening of the shelter's surface. }\end{array}$ \\
\hline & 4 & $\begin{array}{l}\text { Restricted to the SE corner of square } \mathrm{C} 5 \text { (thus, unexcavated), c. } 45 \mathrm{~cm} \text { below the surface, this unit may } \\
\text { correspond to a large (Medieval?) hearth extending to squares } \mathrm{B}-\mathrm{C} 7 \text { and } \mathrm{C} 6 \text { with numerous potsherds } \\
\text { around it with no signs of exposure to fire. }\end{array}$ \\
\hline & 5 & $\begin{array}{l}\text { Over a huge boulder (likely collapsed from the shelter's roof), this is a sandy, yellowish layer resulting from } \\
\text { altered granite, with scarce, mixed archaeological artefacts both Neolithic and Medieval. }\end{array}$ \\
\hline & 6 & $\begin{array}{l}\text { Dark grey layer located in front of the shelter's wall, in square E8 (therefore, not visible in profile C-D9), } \\
\text { thicker near the wall and thinner towards the exterior [6a], c. } 30 \text { and } 15 \mathrm{~cm} \text { thick, respectively. It may } \\
\text { result from the use of the hearth found in Test } 2 \text { (unit [10]). It revealed medieval potsherds, bones and } \\
\text { charcoal. }\end{array}$ \\
\hline
\end{tabular}

7 Brown-coloured sediments, $8-20 \mathrm{~cm}$ thick, archaeologically sterile (only a few faunal remains were found), probably corresponding to an abandonment phase between the prehistoric occupations recorded in unit [8] and the overlying, medieval strata.

Coarse grained, yellowish sediments, c. $15 \mathrm{~cm}$ thick, with abundant Neolithic artefacts. This layer records the last attested Neolithic occupation at Penedo dos Mouros.

9 Very dense, carbonaceous layer with very irregular micro-topography but always marking the interface between units [8] (or [10] where this is visible) and [11]. Its particular topography in the squares of row 8 indicates this was formed by low energy water percolation processes, carrying with it charcoal (of Erica arborea and Quercus suber) originated from the upper layers and redeposited here. A charcoal sample was dated to $1,147 \pm 30 \mathrm{BP}$, that is, a phase immediately predating the building of the medieval settlement. It separates the unit [8] from the underlying layer [11].

Level of slab-like granite blocks, disposed horizontally without contiguity among themselves (that is, not forming a coherent level). These are lying on top of layer [9], causing the slabs' lower surfaces to be incrusted with charcoal.

11 Loose, sandy sediments, of brownish colours, darkened due to charcoal/ash particles, presenting a NE-SW slope (i.e., pointing to the shelter's exterior), with granitic clasts. Its topography is very variable due to the overall stratum inclination and to irregular substratum (altered granite affected by erosive channels), thus oscillating between 15 and $40 \mathrm{~cm}$, with an average of around $40 \mathrm{~cm}$ thick. It preserves the oldest Neolithic occupation at the site.

Accumulation of rounded granitic clasts (c. $10-15 \mathrm{~cm}$ length), forming an filled circle of around $50 \mathrm{~cm}$ in the SE corner of square C7 (artificial level 3); below these clasts there were also round blocks seemingly forming a base upon which the former were based. The burned aspect of the granitic clasts and greyish infill (ashes?) suggests a hearth.

Set of granitic slabs, around $25-30 \mathrm{~cm}$ length, apparently burned, deliberately overlying each other and transversally aligned to the shelter's (artificial level 3). Remains of a wind shield related to the former hearth?

Accumulation of granitic blocks, $25-30 \mathrm{~cm}$, in the Test's SE corner, likely of human origin but of unclear function. 
TABLE 1 (Continued)

\begin{tabular}{|c|c|c|}
\hline Unit & Field description & $\begin{array}{l}\text { Chronological } \\
\text { attribution }\end{array}$ \\
\hline 6 & $\begin{array}{l}\text { Brown sandy sediments with poorly rounded fine gravel }(<5 \mathrm{~mm} \text { thick) interleaved with ash layers, } \\
\text { corresponding to the abandonment of the pit hearths referred to as units [8] and [10]. }\end{array}$ & \\
\hline 7 & $\begin{array}{l}\text { Level of sandy sediments, greyish in colour (due to large amount of ash and charcoal from cleaning pit } \\
\text { hearths), extending to most of the tested area. Intrusive Neolithic sherd. }\end{array}$ & \\
\hline 8 & Pit and its infilling in the Test's eastern corner. & \\
\hline 10 & $\begin{array}{l}\text { Pit hearth located in the Test's NW corner }(60 \times 22 \mathrm{~cm} \text { width), filled with large quantities of charcoal and } \\
\text { ashes accumulated in numerous fine layers interspersed with fine-grained sands, likely corresponding } \\
\text { to successive uses of the same pit as hearth. }\end{array}$ & \\
\hline 11 & $\begin{array}{l}\text { Stone accumulation below units [7] and [9], probably corresponding to the collapse of a Neolithic } \\
\text { windbreak. }\end{array}$ & Neolithic \\
\hline 12 & Grey sediments in the NW corner of the Test, below unit [7], of Neolithic age. & \\
\hline
\end{tabular}

artefactual assemblages (mainly pottery) along with abundant botanic remains of pulses and cereals infers the presence of a granary associated with domestic use of the site (Tente, 2007, 2010, 2012/2013).
The wall platform is surrounded by steep slopes except on the Southeast, where the original entrance must have been located. The Neolithic deposit was found in a sheltered surface measuring less than $30 \mathrm{~m}^{2}$ produced by detachments along joints in the largest

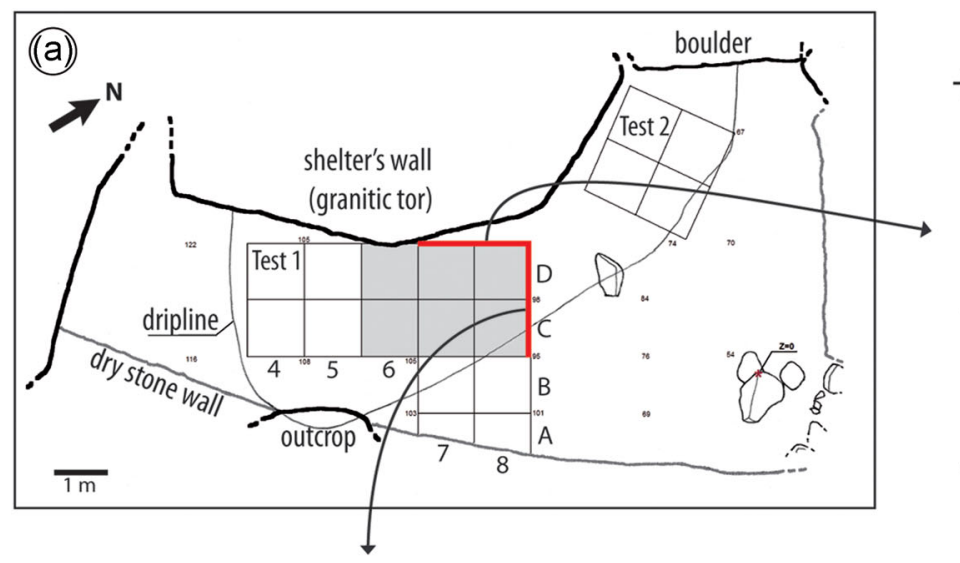

(C)) $\mathrm{D} 9 \mathrm{~T} \quad \mathrm{C9} \quad 7$
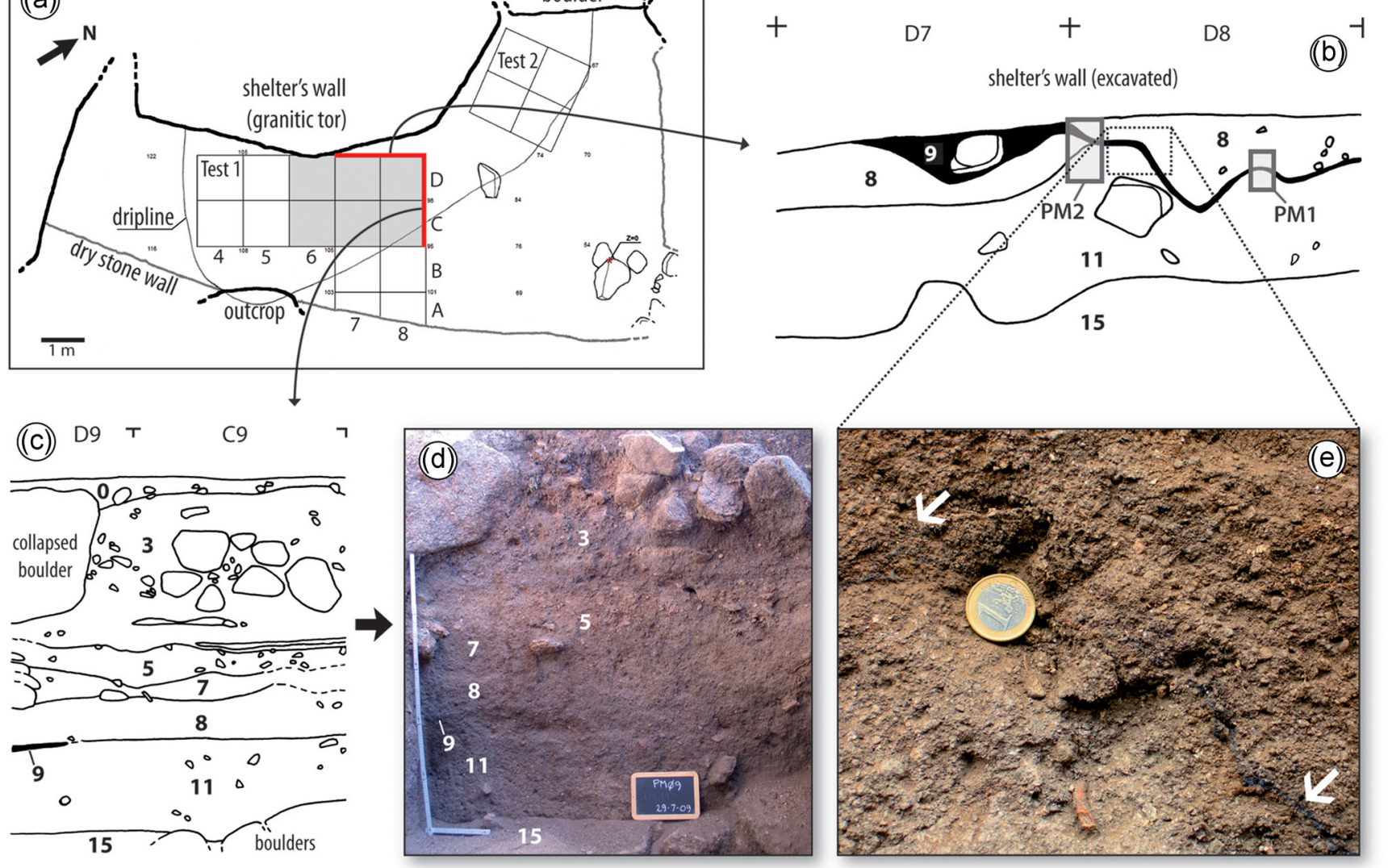

FIGURE 2 Penedo dos Mouros rockshelter. (a) Plan of the site with the location of the test pits. (b) Neolithic stratigraphy of the sampled profile in squares D7/D8, with the location of the micromorphological samples PM1 and PM2. The hardpan (layer 9) is represented by a black fill. (c) Profile in squares D8/C8 of Test 1. (d) Photograph of the same profile and note the general homogeneity of the Neolithic deposit (layers 8,9 and 11). (e) Detail of layer 9 (indicated with arrows), with the location marked in b (Euro coin for scale) [Color figure can be viewed at wileyonlinelibrary.com] 

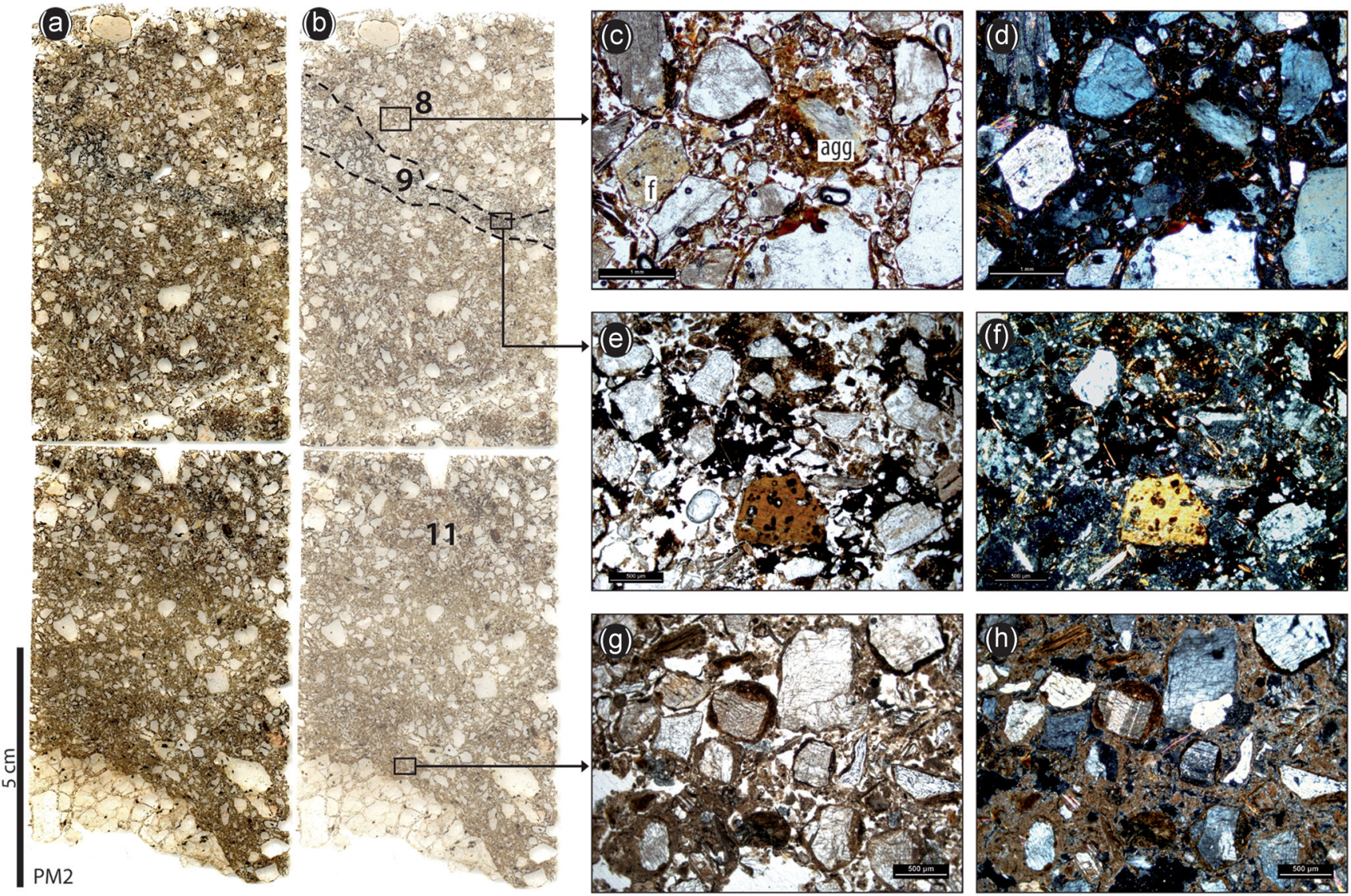

FIGURE 3 The Neolithic layers of Penedo dos Mouros in a thin section. (a) Flatbed scan of thin sections PM2a (above) and PM2b (below). Note the absence of sedimentary structures and the poor sorting of sand, as well as abundant gravelly grains and a centimetre-sized clast in the bottom; (b) same as (a), with contacts and layers designations annotated. (c and d) Representative microphotographs of layer 8 general aspects, PPL and XPL, respectively. Note the dark to brown fine material overall isotropic in XPL, with exception of silty particles of mica and microcrystals of secondary minerals resulting from feldspar alteration (stipple speckled b-fabric); note a relict soil aggregate with bioturbation channels [agg] and a weathering feldspar forming sericite [f], scale: $1 \mathrm{~mm}$. (e and f) Representative microphotographs of layer 9, PPL and XPL, respectively. Note the dark material cementing the components, totally isotropic in XPL, scale: $500 \mu m$. (g and h) Representative microphotographs of layer 11, in PPL and XPL, respectively, where the calcareous matrix, absent in upper levels, is visible. Note the wellrounded organic silt coatings around grains, scale: $500 \mu \mathrm{m}$. PPL, plane-polarized light; XPL, crossed-polarized light [Color figure can be viewed at wileyonlinelibrary.com]

granite tor, in the south rim of the platform, the Penedo dos Mouros Rockshelter (Figure 1d,e). The slope bordering the platform on the southern and western sides are drained by a seasonal rill towards the Boco valley (Figure 1d). This seasonal stream creates a particularly moist microenvironment during rainy seasons and had a role to play in site formation processes and corresponding faunal records (see below). Excavations were undertaken at the rockshelter in 2008 to test the medieval occupation. Around a 1-m-thick strata containing medieval potsherds and abundant phytoliths (ashes, straw, cereal ears and wild grasses) were identified in Test 1 and interpreted as an embankment of a levelled surface created for the establishment of a sheepfold during the 10th century (Figure 1e). Below the medieval embankment, Neolithic pottery and knapped stone, associated with a small faunal assemblage, were unexpectedly recovered in the bottom layers. Test 1 was thus enlarged in 2009 and 2011 to investigate in more detail the oldest occupation in stratigraphic and archaeological terms.
This Neolithic deposit is represented by rare, small pottery vessels, some of which are decorated with cordoned, impressed and incised motifs, associated with handles. Except for a few chips and one flint bladelet (an imported raw material), most of the knapped assemblage (around 98\%) is made of local rocks (mainly milky quartz). Fifty-six bone elements were recovered along with the Neolithic artefacts. This faunal assemblage is composed of sheep (and goat?, $n=3)$, swine $(n=1)$, rabbit $(n=7)$, hare $(n=3)$, Iberian lynx $(n=1)$ and toad $(n=1)$. The archaeostratigraphy associated with this artefactual assemblage spans from the late fifth to the fourth millennia, thus encompassing the end of the Early Neolithic and the emergence of the earliest megalithism in the region, that is, the Middle Neolithic, which is, respectively, layers 11 and 8 . In terms of structures, a group of granite boulders within the basal layer 11 , seems to have been placed to build a small hearth and associated windbreak. These findings make Penedo dos Mouros an important reference site for the understanding of the neolithization process in Serra da Estrela as 
TABLE 2 Penedo dos Mouros Rockshelter: Radiocarbon determinations

\begin{tabular}{|c|c|c|c|c|c|c|c|}
\hline Test & Layer & Sample & $\begin{array}{l}{ }^{14} \mathrm{C} \text { Lab. } \\
\text { number }\end{array}$ & $\delta^{13} \mathrm{C}(\%)$ & Years BP & $\begin{array}{l}\text { Cal range B.C./A.D. } \\
(95.4 \% \text { prob. })^{a}\end{array}$ & Comments \\
\hline \multirow[t]{4}{*}{1} & 07 & $\begin{array}{l}\text { Fragment of mandible } \\
\text { (Canis familiaris) }\end{array}$ & Wk-27462 & - & - & - & $\begin{array}{l}\text { Abandoned; no } \\
\text { collagen. }\end{array}$ \\
\hline & 09 & Charcoal (Erica arborea) & Wk-25818 & -25.0 & $1,147 \pm 30$ & 776-974 cal A.D. (95.4\%). & Medieval occupation. \\
\hline & 09 & $\begin{array}{l}\text { Bone fragments (unknown } \\
\text { species) }\end{array}$ & Wk-25159 & - & - & - & $\begin{array}{l}\text { Abandoned; no } \\
\text { collagen. }\end{array}$ \\
\hline & 11 & $\begin{array}{l}\text { Epiphysis of metacarpal } \\
\text { (Ovis aries) }\end{array}$ & Wk-35998 & b & $3,559 \pm 27$ & $\begin{array}{l}2,013-1,999 \text { cal B.C. (2.0\%); } \\
1,979-1,871 \text { cal B.C. (79.7\%); } \\
1,846-1,812 \text { cal B.C. (8.2\%); } \\
1,803-1,777 \text { cal B.C. }(5.5 \%) \text {. }\end{array}$ & Rejected. \\
\hline \multirow[t]{2}{*}{2} & 12 & Fragment of mandible (Sus sp.) & Wk-25160 & - & - & - & $\begin{array}{l}\text { Abandoned; no } \\
\text { collagen. }\end{array}$ \\
\hline & 13 & Charcoal (Erica sp.) & Wk-25158 & -24.9 & $2,375 \pm 30$ & $\begin{array}{l}702-696 \text { cal B.C. }(0.6 \%) ; \\
541-390 \text { cal B.C. }(94.8 \%)\end{array}$ & Intrusive; percolation? \\
\hline
\end{tabular}

${ }^{a}$ Calibrations according to IntCal13 atmospheric curve (Reimer, Bard, \& Bayliss, 2013) with OxCal program, version 4.2 .4 (Bronk Ramsey, 2013 ).

${ }^{b}$ Comments from the laboratory: Because of the small size of this sample, the Carbon 13 stable isotope value $\left(\delta^{13} \mathrm{C}\right)$ was measured on prepared graphite using the AMS spectrometer. The radiocarbon date has therefore been corrected for isotopic fractionation. However, the AMS-measured $\delta^{13} \mathrm{C}$ value can differ from the $\delta^{13} \mathrm{C}$ of the original material and it is therefore not shown.

it constitutes the oldest known evidence for herding practices in the region, coeval with important cultural changes within Neolithic societies despite the poor preservation of bone remains (Carvalho et al., 2017).

\section{MATERIALS AND METHODS}

Micromorphology is the study of thin sections of undisturbed and oriented block samples of a sedimentary context under the petrographic microscope (Courty, Goldberg, \& Macphail, 1989, Nicosia \& Stoops, 2017). At Penedo dos Mouros, two sediment block samples were collected in the profile D7/D8 (Figure 2b), including the transition between layers 8, 9 and 11, thus cross-cutting the hardpan. This strategy focused first, on targeting the transition from the Early to the Middle Neolithic strata and second, to obtain more data related to horizontal variations of the hardpan (layer 9) and the significance of stratigraphic contacts. We only analysed layers 8-11 (Figure 2b-e and Table 1), since the upper ones post-date the Neolithic.

The samples were processed by the Servei de Micromofologia i Anàlisi d'Imatges at the University of Lleida (Spain) and three $5.7 \times 13.5 \mathrm{~cm}$ thin sections were obtained. The thin sections were digitally scanned for analysis at 1:1 scale and then at higher magnifications (Arpin, Mallol, \& Goldberg, 2002). The microscopic examination was carried out under stereoscopic and petrographic microscopes with magnifications between $\times 20$ and $\times 400$ in planeand crossed-polarized light, oblique incident light, and fluorescent blue light (BL). The thin section descriptions followed the methodology and terminology established by Courty et al. (1989) and Stoops (2003). Additional geochemical characterization of specific areas in the thin section considered of interest was undertaken by scanning electron microscopy-energy-dispersive X-ray spectroscopy (SEM-EDS; Weiner, 2010; C. A. Wilson, 2017).

\section{3 | RESULTS}

\section{1 | Sedimentary components}

The sediment in all thin sections is comprised of unsorted coarse sand varying from rounded to angular with low to a high degree of sphericity (see Table 3 for descriptions). The distribution and concentration of both clastic and organic basic components do not vary throughout the sequence in thin sections, neither are any internal sedimentary structures identified (Figure 3a,b). Geogenic grains reflect the lithological granitic environment (quartz, feldspars, muscovite and biotite; Table 3, see also Figure 3c-h). Fine to coarse gravel also occurs together with unsorted sand in $50 \%$ of the thin sections (Figure 3a-h). Bone fragments and charcoal were observed in thin section and must be considered an anthropogenic input. Burnt and manganese-stained bones occur in layer 9 and carbonate mineralization is seen in layer 11 (Figure $4 a-c$ ).

Mineral silt-sized particles (2-63 $\mu \mathrm{m} ; \sim 20 \%$ ) consist of alteration products of biotite, muscovite and feldspar, such as sericite. Silt and fine sand particles can be found either loose or contained in aggregates composed mostly of organic fine material, whereas clay is practically nonexistent. The aggregates are dark brown, optically isotropic, rich in micro-charcoal and charred or humified plant material, overall considered as polymorphic fine organic matter (Figure 3c,d).

Layer 11 is distinctive for the presence of calcium carbonate matrix (Figure 3g,h) and components. Among these are calcined plant fragments, recognizable by their cellular structure, which has been totally replaced by calcium carbonate and thus preserving the original form of the organic tissue (Figure 4d). Calcium oxalate pseudomorphs, or ash rhombs (Canti, 2003; Canti \& Brochier, 2017b; Mentzer, 2014), are also present in layer 11, being the main component of many of the aggregates (Figure $4 d-g$ ). 
TABLE 3 List and description of the basic sedimentary components identified in thin sections from Penedo dos Mouros

\begin{tabular}{|c|c|}
\hline Component & Description and comments \\
\hline Rock fragments & $\begin{array}{l}\text { Rock fragments are the most abundant component ( } 30 \% \text { of the coarse mineral fraction) throughout the sampled } \\
\text { sequence, presenting the full or partial association of the granite rock, from fine sand size to few cm. Shapes } \\
\text { are rounded to angular. In general, they present intense weathering and fragmentation. }\end{array}$ \\
\hline Quartz & Represents $20 \%$ of the coarse mineral fraction. Sizes range from silt to several $\mathrm{mm}$. Shapes are rounded to angular. \\
\hline Feldspar & $\begin{array}{l}\text { K-feldspar (mainly microcline) and plagioclase grains represent } 20 \% \text { of the coarse mineral fraction. Size ranges } \\
\text { from silt to medium sand and shapes from rounded to angular. Overall K-feldspars and plagioclase show } \\
\text { advanced degree of alteration to microcrystalline minerals in weathering fissures, most probably sericite. }\end{array}$ \\
\hline Biotite & $\begin{array}{l}\text { Abundant, ( } 10 \% \text { of the coarse mineral fraction) as well-preserved and highly weathered crystals. Size ranges from } \\
\text { silt to medium sand size. Normally exhibits its characteristic platy shape with fibrous aspect, but it is } \\
\text { observable as well in its basal section, being possible to recognize the characteristic hexagonal crystalline } \\
\text { shape. Some biotite grains contain zircon crystals, easily recognizable by its characteristic crystalline shape, } \\
\text { with high relief and high interference colours. }\end{array}$ \\
\hline Muscovite & $\begin{array}{l}\text { Abundant ( } 10 \% \text { of the coarse mineral fraction), both fresh and weathered. Normally exhibits its characteristic platy } \\
\text { shape with fibrous aspect. Size ranges from silt to medium sand size. }\end{array}$ \\
\hline Other minerals & $\begin{array}{l}\text { Silt to fine sand sized, rounded grains composed of microcrystalline minerals result of feldspars alteration } \\
\text { (presumably sericite). }\end{array}$ \\
\hline Plant material & $\begin{array}{l}\text { Fragments of plant tissue with visible internal structure are frequent, presenting advance decomposition and } \\
\text { charring. In the carbonated layer } 11 \text { they present calcitic recrystallization, preserving the original articulated } \\
\text { structure, with signs of combustion. }\end{array}$ \\
\hline Charcoal & $\begin{array}{l}\text { Silt-size and dusty charcoal is a main component of the fine fabric, whereas coarser fragments are rare. The few } \\
\text { fragments present sizes up to } 1 \mathrm{~mm} \text { and the internal structure generally damaged. }\end{array}$ \\
\hline Ashes & $\begin{array}{l}\text { Micritic pseudomorphs of rhombohedral calcium oxalates after combustion, preserving the original rhombohedral } \\
\text { shape of the monocrystals of calcite oxalate naturally present in vegetal fibres, with pale yellow to grey colour } \\
\text { and highly birefringent, are present within aggregates among other silty materials, concentrated in the base of } \\
\text { the sampled sequence (layer 11). Aggregates of cemented and articulated ashes also occur and are interpreted } \\
\text { as indicative of transport after disturbance of the original combustion place. }\end{array}$ \\
\hline Mollusc shell & $\begin{array}{l}\text { Scarce shell remains, most likely terrestrial gastropods, are present in the bottom of the carbonated ashy zone of } \\
\text { level } 11 \text {, with corroded borders indicative of dissolution. }\end{array}$ \\
\hline Iron-manganese nodules & In-situ impregnative nodules and inherited well-rounded typic nodules, both dark and isotropic. \\
\hline Elements of biological activity & $\begin{array}{l}\text { Fresh roots are common, in various classes of decomposition, systematically associated with discontinuous } \\
\text { infillings of ellipisoid and bacillo-cylinders oribatid mite excrements }\end{array}$ \\
\hline
\end{tabular}

\section{2 | Sedimentary microfabric}

It is possible to distinguish three main patterns of organization and composition of the solid part of the sediment in thin section formed by fine material, namely, granular microfabric, crumbs microfabric and coated grains microfabric. The three patterns coexist and are evenly represented in the three layers. It was possible to isolate each one based in their geometry in thin section (Figure 5), thus allowing for the interpretation of different processes involved in the deposit formation.

Granular microfabric consists of silt and fine sand-sized granules between coarser aggregates and grains. In layers 8 and 9, this pattern is composed of individual organic particles (Figure 5), for example, micro-charcoal, soil micro-fauna excrements and polymorphic fine organic matter. In turn in layer 11 , this pattern is widely characterized by micritic calcite microaggregates and ash rhombs, although organic components mentioned above also occur.

The crumb microfabric refers to medium to coarse sand size and occasionally larger aggregates, that exhibit a crumby structure with diffuse limits and irregular shapes with internal porosity that includes channels, silt-sized to fine-sand mineral, and charred and humified organic inclusions. The isotropic, brown micromass of these aggregates constitute the rare instances where some clay was observed, but overall they appear to be mainly organic and composed of micro and dusty charcoal (Figures 3c,d and 5).

The third pattern consists of grains coated with well-rounded layers of finer material with massive microstructure, that is, without internal porosity, presenting a virtually spherical geometry. These coated grains are often a single archaeological or lithological component of any grain size, coated by one or two silty, organic or calcitic concentric layers (Figures $3 \mathrm{c}$ and $3 \mathrm{~g}$, and 5).

The void space overall corresponds to a single pattern, characterized by complex packing voids, resulting from simple accumulation of the solid elements of different compositions. In layers 9 and 11 , this void pattern is masked by post-depositional processes, explained below, creating closed vughs. 

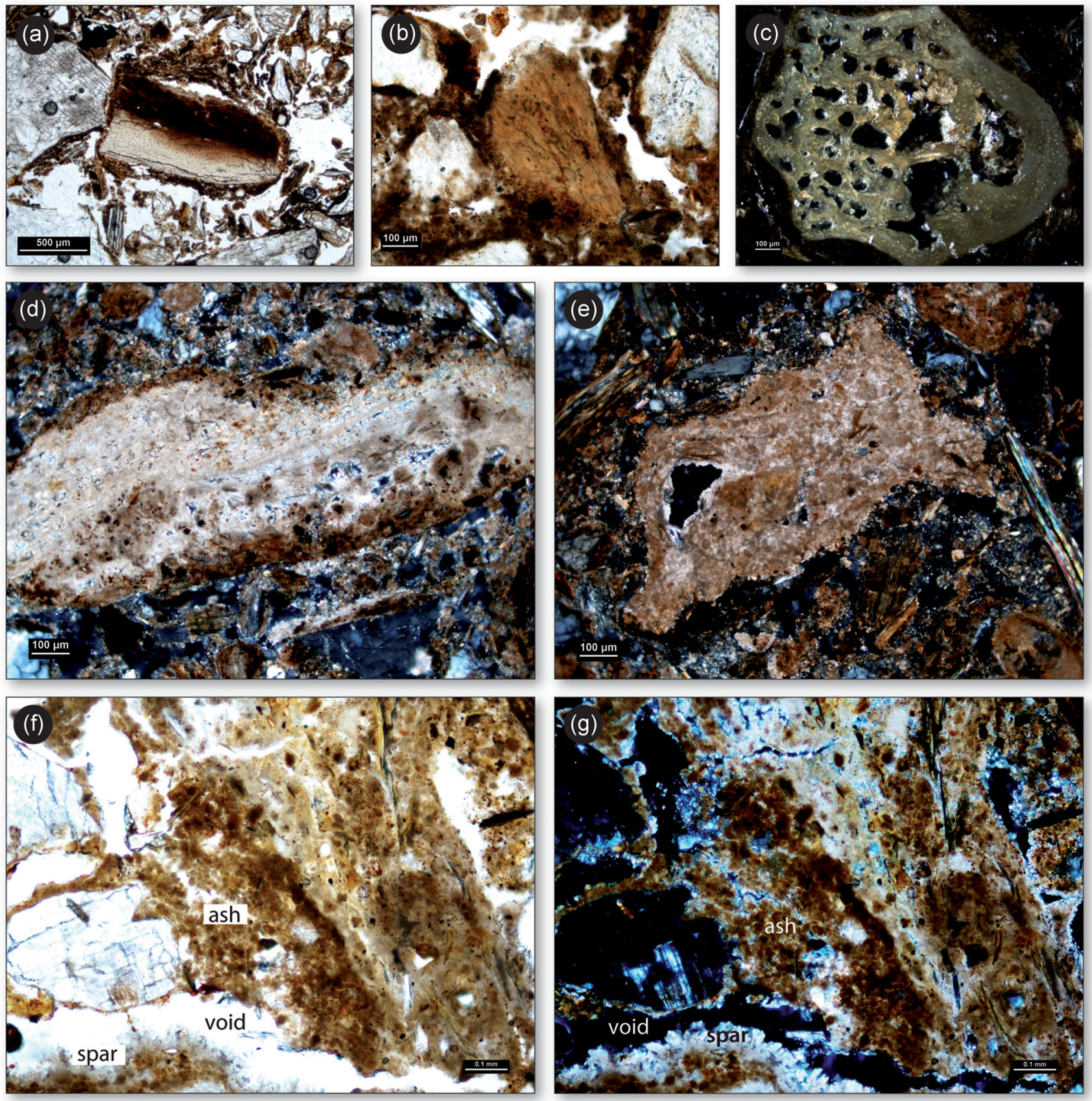

FIGURE 4 Anthropogenic combustion residues at Penedo dos Mouros. (a) Partially burnt bone fragment from layer 8 (PPL, scale: $500 \mu \mathrm{m}$ ). (b) Layer 9, example of a bone with staining spots, likely by manganese (PPL, scale: $100 \mu \mathrm{m})$. (c) Bone undergoing strong carbonate mineralization in layer 11, in OIL, where it is visible in the bone tissue of the overall enrichment in Ca by its brightness and secondary calcite recrystallization in the pores (scale: $100 \mu \mathrm{m}$ ). (d) Fragments of burnt and calcified plant material, note the fibrous cellular structure still visible (XPL, scale: $100 \mu \mathrm{m})$. (e) Aggregate of wood ash composed of pseudomorphic rhombs of calcium carbonate (XPL, scale: $100 \mu \mathrm{m})$.

(f) Concentration of ash rhombs [ash] and surrounding matrix cemented with micrite, note the growth of micro-sparite crystals [spar] filling the void over the surface of a clast; (PPL, scale: $0.1 \mathrm{~mm}$ ). (g) Same as (f), but XPL, where the secondary carbonates features are better seen. PPL, plane-polarized light; OIL, oblique incident light; XPL, crossed-polarized light [Color figure can be viewed at wileyonlinelibrary.com]

\section{3 | Post-depositional processes}

The prehistoric deposit was influenced by post-depositional processes that can be divided in two groups based on the type of microscopic features: monomorphic organic and crystallitic features.
Monomorphic organic features consist of organic fine material and is practically restricted to layer 9. It is composed of massive, amorphous material, without any coarser inclusion or internal porosity. Most of it is opaque (Figures 3e,f and $6 a-c$ ), but a limpid type also occurs more rarely, which has an orange colour, low 
Granular microfabric

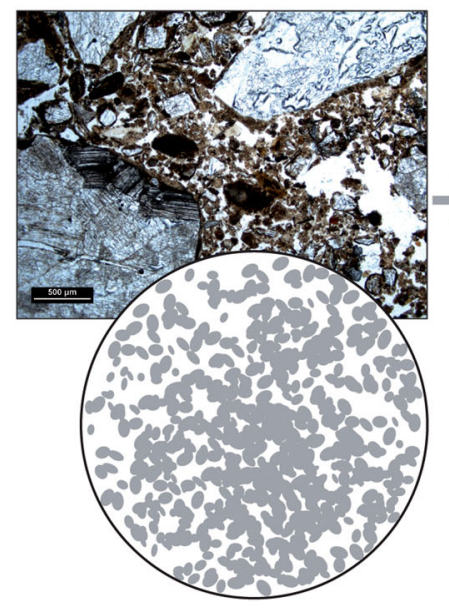

Crumb microfabric

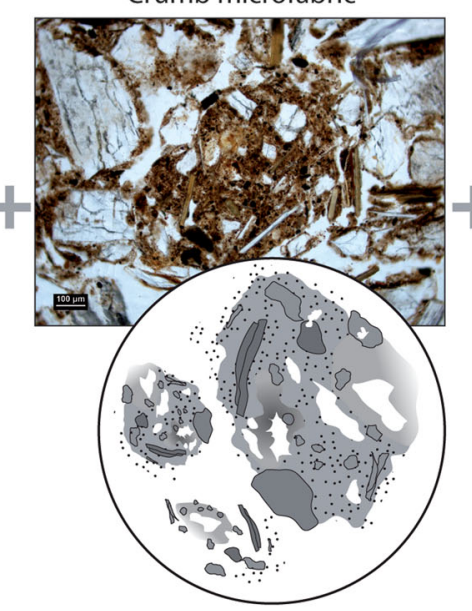

Coated grain microfabric

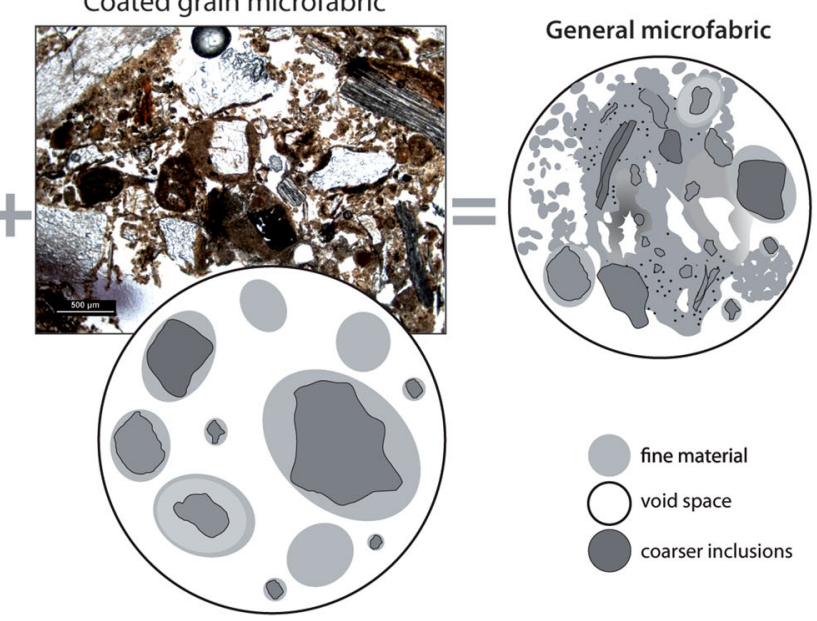

FIGURE 5 Schematic representation of the three sedimentary microfabrics observed in Penedo dos Mouros thin sections.

Microphotographs show selected areas representative of each pattern. Graphic representations synthesize the characteristics of each pattern described in the text [Color figure can be viewed at wileyonlinelibrary.com]

birefringence and high fluorescence under BL (Figure 6d-f). Similar type of monomorphic coating features has been pointed out as being enriched in organo-metallic particles, such as aluminium, as result of its organic colloidal nature (Wilson \& Righi, 2010). In layer 9, monomorphic fine organic matter cements the deposit, forming the hard pan identified during excavation (Figure 2b,e). Such cement coats the grain surfaces and aggregates, and forms bridges between them (Figure 6c). This mass present polygonal fissures (Figure 6b), indicative of dehydration of the colloidal gels that formed them (Buurman \& Jongmans, 2005; M. A. Wilson \& Righi, 2010).

Crystallitic (calcitic) post-depositional features are restricted to layer 11 , as seen previously with the calcitic coarse and fine components. These include a few calcified roots or rhizoliths (Figure 7a), and micritic coatings and hypocoatings in pore surfaces that lead to the formation of closed vughs (Figure 7b). The most abundant carbonate features are pendants (Figure 7c,d), formed by alternating micrite and micro-spar laminae, with variable amounts of organic inclusions and iron oxides. These pendants are formed under vadose conditions of percolating water saturated in calcium carbonate (Durand, Monger, \& Canti, 2010; Stoops, Marcelino, \& Mees, 2010).

\section{4 | DISCUSSION}

\section{1 | Sediment accumulation}

The lithological components of Neolithic deposit at Penedo dos Mouros reflect the local granitic rock, highly weathered, attested in thin section by typical features, for example, cracking and disaggregation of clasts filled with secondary minerals, such as sericite in the case of feldspars (Figures 3c and 6c; Taboada \& Garcia, 1999). These features are inherited from the saprolization and arenization of the bedrock at regional scale (Sequeira Braga, Paquet, \& Begonha, 2002). The deposit of the rockshelter is thus possibly the result of accumulation of saprolitic debris from erosion of the surrounding soils, with archaeological inclusions. Angelucci et al. (2004) described the local soils as type $\mathrm{A}-\mathrm{C}$, where the surficial A-horizon directly lies on C-horizon, the altered bedrock, without a transitional B-horizon. However, at Penedo dos Mouros rockshelter, pedogenesis has led to the formation of a hardpsan, layer 9.

Micromorphological analysis provides clues concerning the sediment microfabric types. The granular microfabric with mixed excrements is associated with the activity of insects in the soil (Courty and Fedoroff, 2002; Stoops et al., 2010). This microfabric seems to have been essentially inherited from saprolitic debris bearing fine material that originated from incipient soil formation elsewhere, judging by the presence of soil aggregates as irregular crumbs (Figure 3c). This might indicate continuous sediment accretion, thus a rather unstable surface within the rockshelter.

The well-rounded coated grains seem to be related to the process of sediment transport. The coatings are composed of different types of silty and organic material, with or without internal layering. This type of coated grains is common in sediments transported by slope processes, which contributes to the roundness of these coatings (Bertran \& Texier, 1999; Mücher, 1974). Combined with weak bioturbation, both contributed to the transport and reworking of sediments at Penedo dos Mouros, and consequent generalized homogenization of the deposit. These aspects overall indicate a slow but constant sedimentation, in which all sedimentary components were involved in the sediment transport, within the framework of creep or colluvial processes. The inclusion of soil aggregates and reworked relict earthworm-worked microfabrics, as well as archaeological materials, points to a deposit with colluvial characteristics (Bertran \& Texier, 1999; Macphail \& Goldberg, 2017; Mücher, Steijn, \& Kwaad, 2010). 

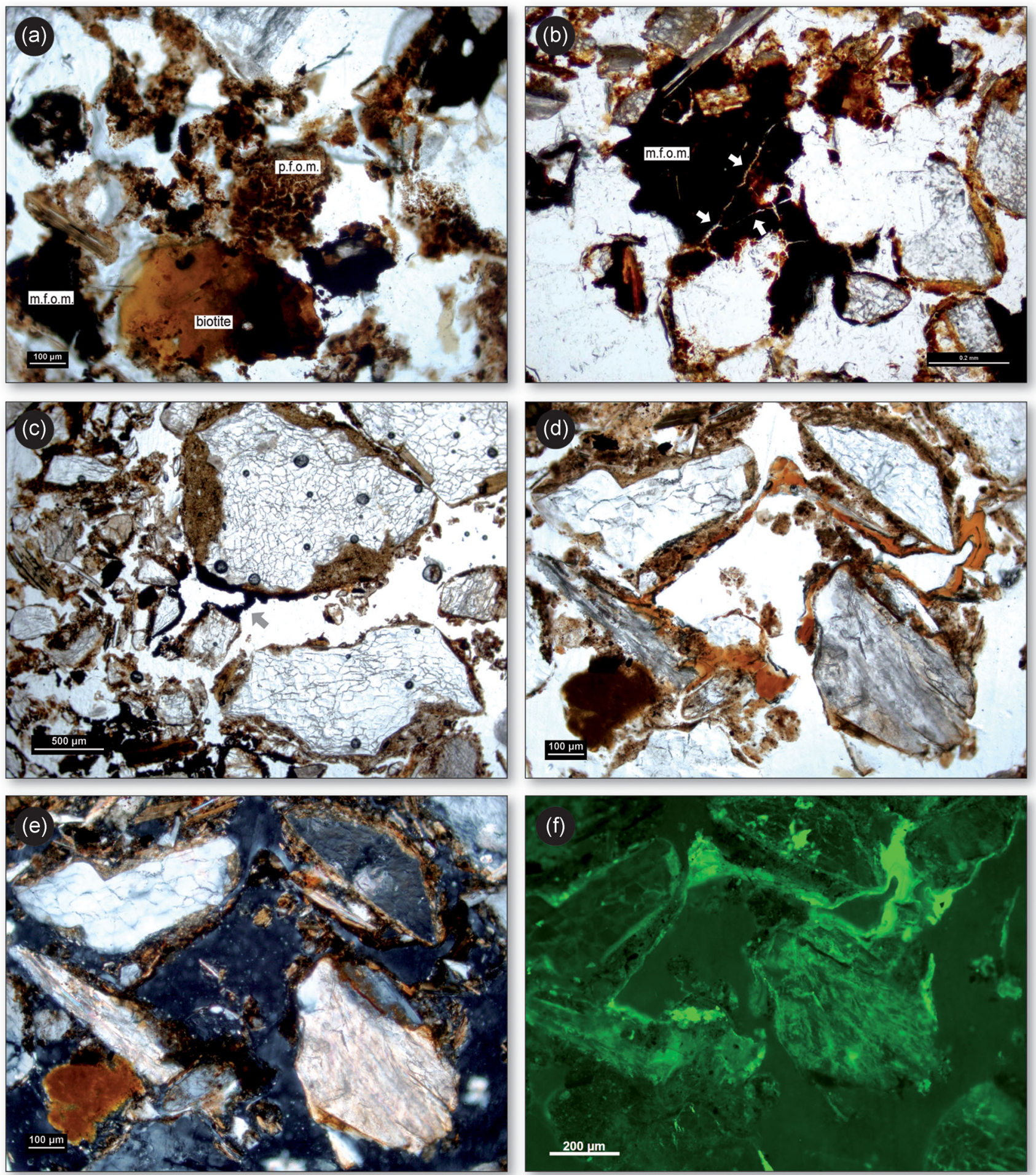

FIGURE 6 Spodic-like features in layer 9 related to fine organic matter. (a) Coalescent pellet of polymorphic fine organic matter [p.f.o.m.] and aggregates of dark monomorphic fine organic matter [m.f.o.m.] (PPL, scale: $100 \mu \mathrm{m})$. (b) Dark monomorphic fine organic matter [m.f.o.m.] exhibiting polygonal fissures (pointed with white arrows) as result of desiccation (PPL, scale: $0.2 \mathrm{~mm}$ ). (c) Microphotograph of the contact between layers 8 and 9. In the lower part, the dark monomorphic material forms a bridge connecting two coarser grains in the centre, note that the quartz grain at the centre-top exhibits rims altered to a secondary microcrystalline yellowish material, and must not be confused with some type of clay coating (PPL, scale: $500 \mu \mathrm{m}$ ). (d) Void coating of limpid orange fine organic matter (PPL; scale: $100 \mu \mathrm{m})$. (e) Same as (a), under XPL, note weak birefringence of the coating (scale: $100 \mu \mathrm{m}$ ). (f) Same as (a) and (b), under BL; the monomorphic material is highly fluorescent (scale: $200 \mu \mathrm{m})$. BL, blue light; PPL, plane-polarized light; XPL, crossed-polarized light [Color figure can be viewed at wileyonlinelibrary.com] 

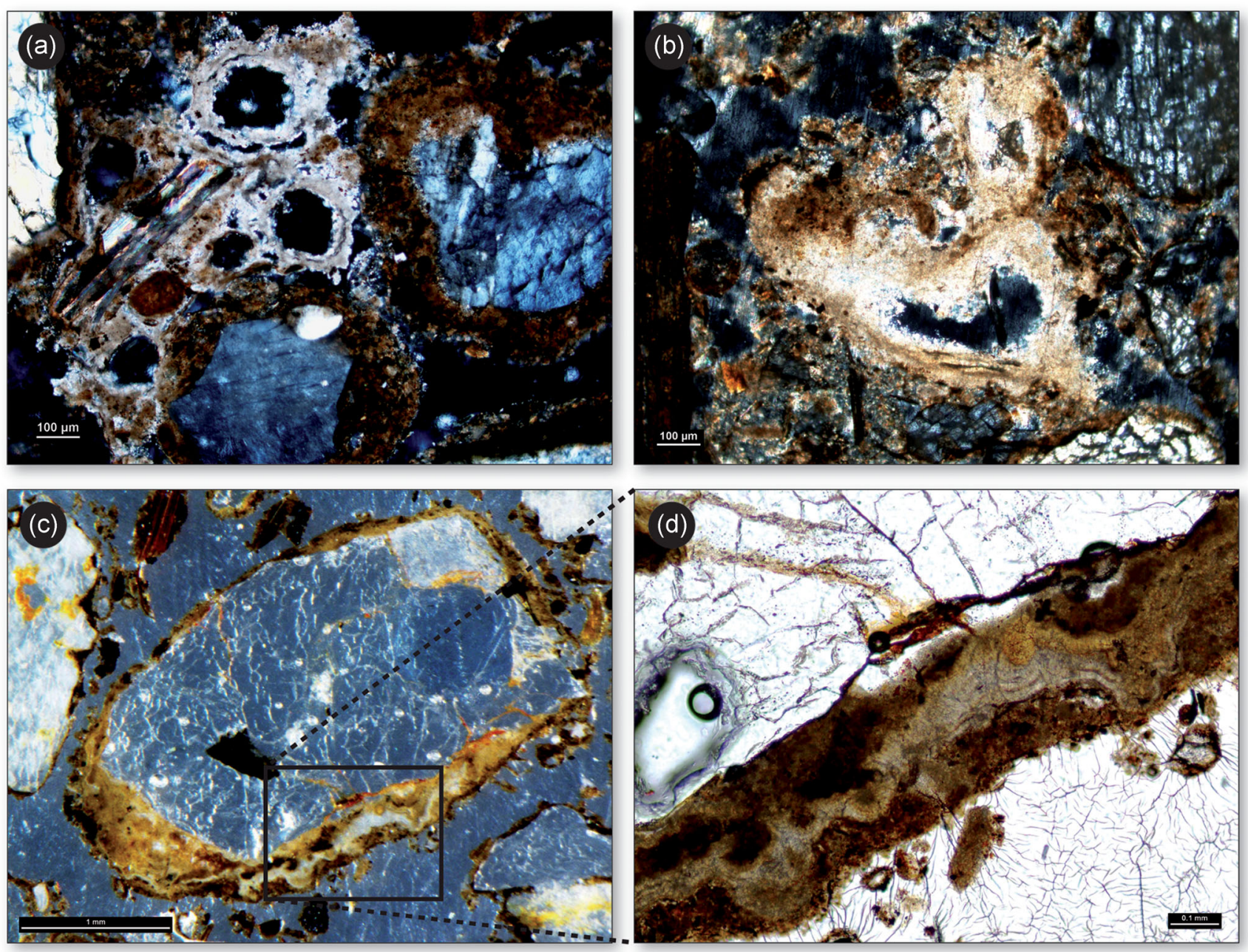

FIGURE 7 Secondary calcium carbonate secondary features at level 11. (a) Calcified roots, or rhizoliths (XPL, scale: $100 \mu \mathrm{m})$. (b) Coating of secondary micrite in void [void] (XPL; scale: $100 \mu \mathrm{m}$ ). (c) Clastic grains with calcitic pendents in the lower part, strikingly visible in OIL (scale: $1 \mathrm{~mm}$ ). (d) Details of the area marked with square in (c), note several phases of crystal growth, with variability in composition indicated by differences in colour (scale: $0.1 \mathrm{~mm}$ ), OIL, oblique incident light [Color figure can be viewed at wileyonlinelibrary.com]

\subsection{Diagenetic processes, ash dissolution and bone preservation}

Layer 11 at Penedo do Mouros present a variety of secondary calcium carbonate features, which is especially intriguing in such an acidic granitic setting that lacks natural sources of calcium where ash is the only identified source. The carbonate materials are both formed in situ and reworked. The former consists of micro-sparitic coatings (Figure $4 \mathrm{f}, \mathrm{g}$ ), indicating that the porosity was filled with water. Another evidence of water saturation in layer 11 is the presence of redox features, mainly iron and manganese impregnations in fine material, such as ash aggregates (Figure 9b,c). These represent post-depositional alteration caused by periods of reducing conditions by water stagnation with dissolved organic matter (Mallol, Cabanes, \& Baena, 2010; Shahack-Gross et al., 2014). Calcitic pendants (Figure $7 \mathrm{c}, \mathrm{d}$ ) also point to secondary precipitation under percolating water conditions. These processes contributed to the carbonate cementation of the lower part of the deposit (layer 11).
Reworked carbonate-cemented materials in layer 11 (Figure $4 c, d$ ) indicate that a similar process (as described above?) occurred within the surroundings, potentially higher up the slope, and were incorporated into the deposit by the transport of sediment into the rockshelter. However, clear dissolution features (e.g., depletion areas or etching of crystal surfaces) are not visible in the thin section. Based on these observations, it is possible that reprecipitation features in layer 11 are derived from dissolved ashes originally present in the upper part of the profile (layers 8 and 9). SEM-EDS analysis undertaken in the two organic-rich aggregates in layers 8 and 9 showed a low percentage of $\mathrm{Ca}$ (Figure 8 and Table 4), respectively, $2.2 \%$ and $5.1 \%$, which in our opinion corroborates that calcium was present in the upper part of the deposit, but did not leave any optical traces. The presence of nonsoluble elements also resulting from combustion (burnt bone, charcoal) in the upper layers (e.g., Figure 4a), together with the general homogeneity of the sediment, strongly suggests that ash was also originally present in the upper deposits within the profile. 
Ash from anthropogenic input, is the only visible source of calcium and indeed one possible hearth feature has been identified during excavation in the middle of layer 11 (Carvalho et al., 2017). The carbonate dissolution and reprecipitation process recorded in the rockshelter deposit post-date the sedimentary accumulation. However, the presence of carbonate crusts with organic coatings, coats formed by ashes and aggregates composed of ashes suggests that this process happened several times, which may relate with the
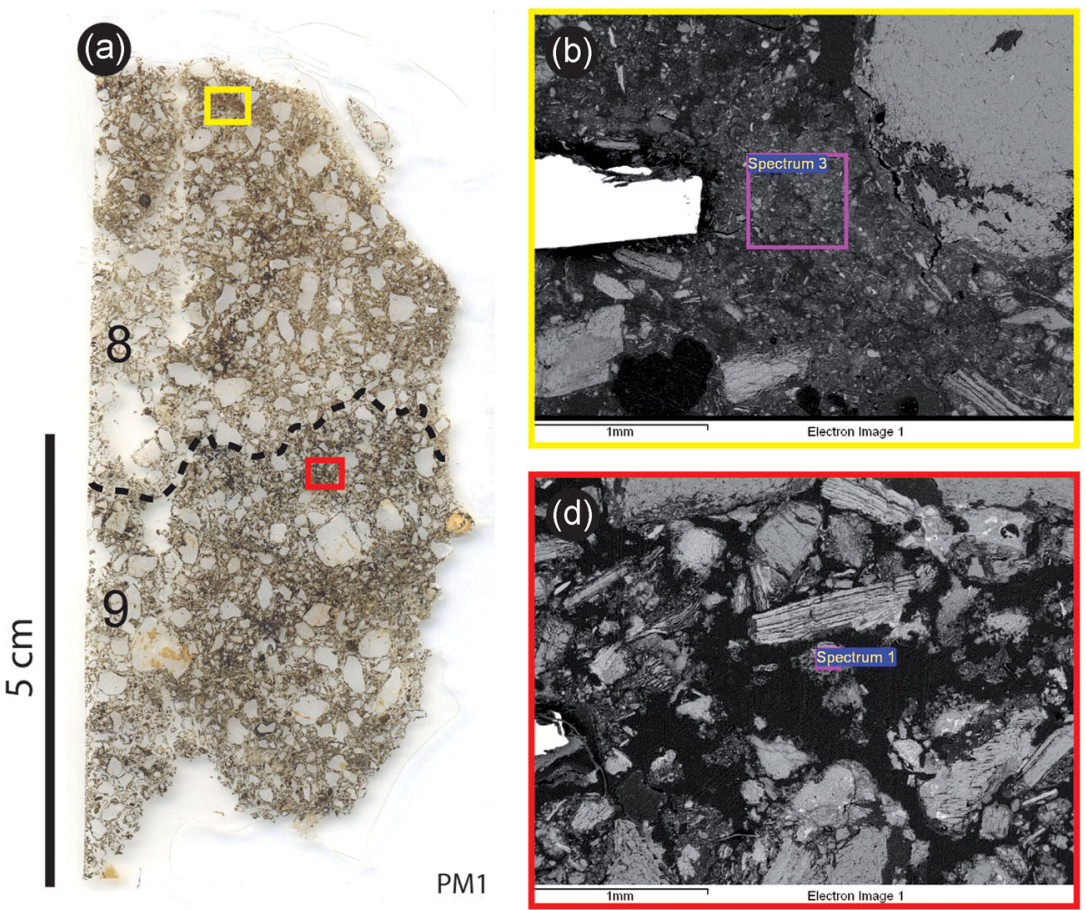
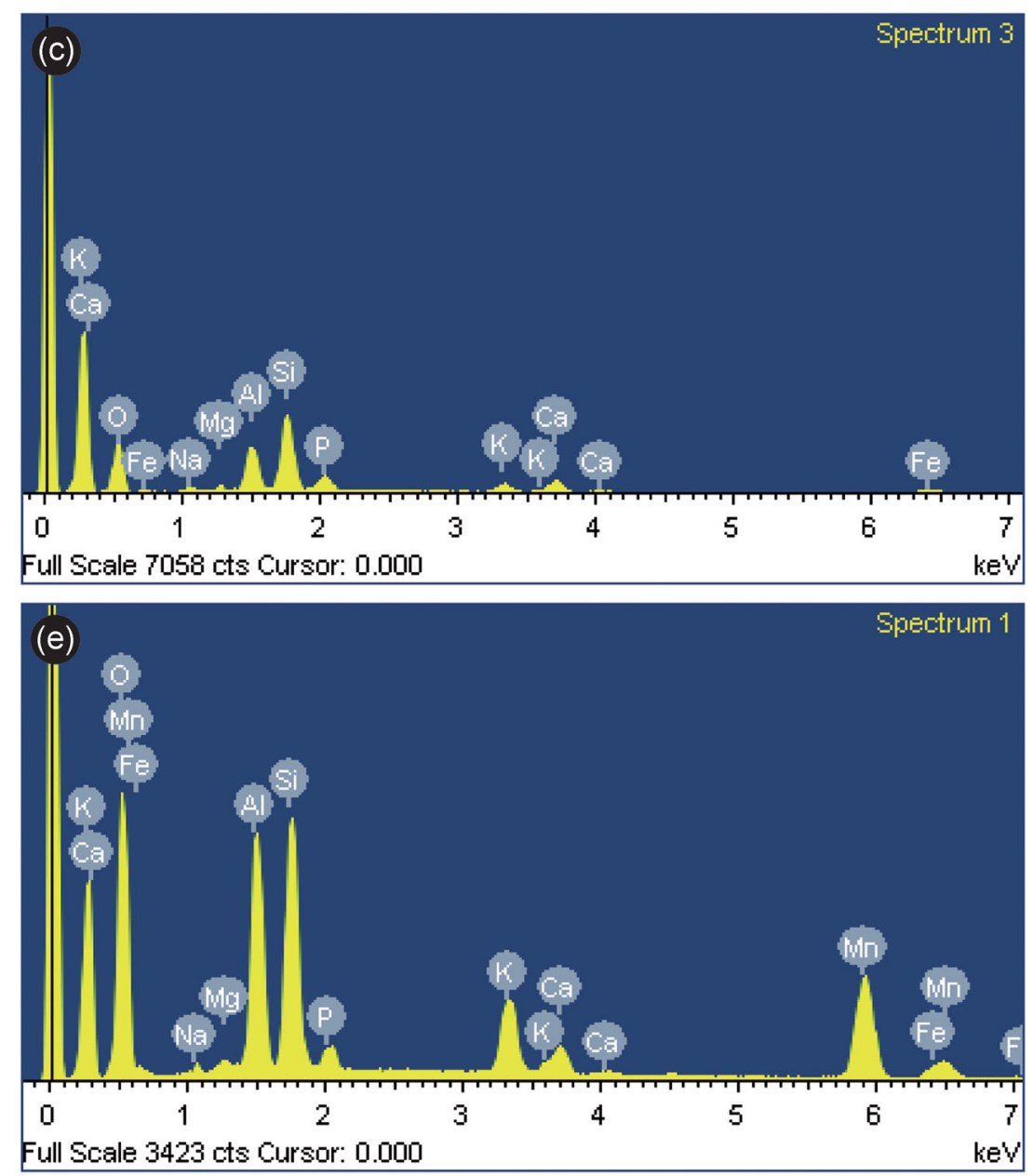

FIGURE 8 SEM-EDS results. (a) Flatbed scan of thin section PM2 with the contact between levels 8 and 9 marked with dashed line and areas analysed highlighted with squares. (b) Back-scattered image of the analysed area of level 8 (yellow square in (a)). (c) Resulting spectrum from the analysed area in level 8, note the presence of $\mathrm{Ca}$. (d) Back-scattered image of the analysed area of level 9, one of the aggregates of dark organic matter (red square in (a)). (e) Resulting spectrum from the analysed area in level 9, note the presence of $\mathrm{Mn}$ and increase in $\mathrm{Al}$ and Si. SEM-EDS, scanning electron microscopyenergy-dispersive $\mathrm{X}$-ray spectroscopy [Color figure can be viewed at wileyonlinelibrary.com] 


\begin{tabular}{|c|c|c|c|c|c|c|}
\hline \multirow[b]{2}{*}{ Element } & \multicolumn{3}{|l|}{ Level 8} & \multicolumn{3}{|c|}{ Level 9 (pan) } \\
\hline & Weight\% & Atomic\% & Compd\% & Weight\% & Atomic\% & Compd\% \\
\hline $\mathrm{Na} \mathrm{K}$ & 1.66 & 1.55 & 2.24 & 0.75 & 0.78 & 1.01 \\
\hline $\mathrm{Mg} \mathrm{K}$ & 1.16 & 1.02 & 1.92 & 0.47 & 0.46 & 0.77 \\
\hline Al K & 10.72 & 8.50 & 20.25 & 12.34 & 10.93 & 23.31 \\
\hline Si K & 21.59 & 16.45 & 46.18 & 15.07 & 12.83 & 32.24 \\
\hline P K & 5.68 & 3.92 & 13.02 & 1.90 & 1.47 & 4.36 \\
\hline K K & 3.46 & 1.90 & 4.17 & 5.94 & 3.63 & 7.16 \\
\hline $\mathrm{Ca} \mathrm{K}$ & 5.06 & 2.70 & 7.07 & 2.19 & 1.31 & 3.06 \\
\hline $\mathrm{Mn} \mathrm{K}$ & - & - & - & 19.73 & 8.59 & 25.48 \\
\hline Fe K & 4.00 & 1.53 & 5.15 & 2.02 & 0.86 & 2.60 \\
\hline $\mathrm{O}$ & 46.67 & 62.43 & & 39.58 & 59.14 & \\
\hline Total & 100.00 & & & 100.00 & & \\
\hline
\end{tabular}

TABLE 4 Chemical components yielded by the scanning electron microscopyenergy-dispersive X-ray spectroscopy analysis of two selected areas of levels 8 and 9 of Penedo dos Mouros periodicity of the human occupations of the site. The micromorphological evidence suggests that ash was spread throughout successive occupation events in the rockshelter, possibly by hearth cleaning, trampling or bioturbation. Ash dissolution and reprecipitation in layer 11, as secondary calcite, promoted alkalinisation allowing for the preservation of the ashes and bones. Furthermore, bones in this layer show evidence of strong carbonate mineralization (Figure 4c).

\section{3 | Manganese crust formation}

The monomorphic and polymorphic fine organic matter at Penedo dos Mouros rockshelter resemble spodic B-horizons (Figure 6a,b; Buurman \& Jongmans, 2005; M. A. Wilson \& Righi, 2010). The predominance of polymorphic fine organic matter above the hardpan (layer 8 ) and the predominance of monomorphic fine organic matter below, creating the hardpan (layer 9) is a recurrent pattern in spodic horizons of non-boreal podzols, and also in sandy well-drained sediments (Buurman \& Jongmans, 2005). Spodic profiles studied by Buurman and Jongmans (2005) showed that cementation by monomorphic fine organic matter is associated with water saturation. A possible explanation for the formation of the hardpan (layer 9) is that the colloidal gels resulting from organic matter decay in upper parts of the deposit encountered a loss of permeability in the sediment that reduced their percolation capacity. A similar manganese crust feature overlying an also impermeable clay layer was documented in Meadowcroft rockshelter (Goldberg \& Arpin, 1999). As there are no changes at sedimentary level, this impermeable barrier at Penedo dos Mouros must have been caused by the calcium carbonate cementation of layer 11, thus predating the hard pan.

SEM-EDS analysis on aggregate within the hardpan (layer 9) and another one above it, within layer 8 (Figure 8 and Table 4), revealed that the composition of the pan is dominated by $\mathrm{Mn}$, closely followed by $\mathrm{Si}$ and $\mathrm{Al}$ as main components. The analysis of the aggregate above the hardpan showed that $\mathrm{Mn}$ is not present, while $\mathrm{Si}(21.6 \%)$ and $\mathrm{Al}$ (10.7\%) are evident. Another element with remarkable counts is $\mathrm{K}$ that together with $\mathrm{Si}$ and $\mathrm{Al}$ reflects the mineralogical composition of the silty material (micas) whilst the similar percentages of $\mathrm{P}$ might be related to the ubiquitous presence of organic matter within the aggregates.

The availability of organic matter, apparently linked to human activity by the production of charcoal and its spreading by trampling, appears to be determinant for the formation of the hardpan. Anthropogenically induced spodic-like conditions are documented in archaeological contexts, occurring in constrained areas below places where human occupations occurred (e.g., Kristiansen, 2001; Macphail, 1989; Mikkelsen, Langohr, \& Macphail, 2007; Villagrán, 2012). The ubiquity and large quantity of fine charcoal and charred plant material in the deposit suggest that the sediments already contain large amounts of these materials that were transformed into grain coatings and rounded aggregates during transport (Figures 3a,g and 9a).

\section{4 | Environmental conditions}

The evidence of sediment transport downslope from eroding saprolitic soils from the surroundings as revealed by the well-rounded coated grains (Figures $5 c$ and 10a), suggests that soil erosion prevailed during the sediment accumulation phase in the rockshelter, coeval with the Neolithic occupations. Meteoric water is the most likely the agent forming the secondary carbonates in layer 11 from ash dissolution, namely from water sources, such as rain and perhaps melting snow, dew or frost, producing the calcitic pendants (Figure 7c,d; Courty et al., 1989). This evidence correlates well with the increasing wet conditions of the Mid-Holocene recorded in the pollen sequence from mountain lakes (Van der Knaap \& van Leeuwen, 1995). The combination of features like redox, micro-spar coatings and calcitic hypocoatings in layer 11 , as well as 

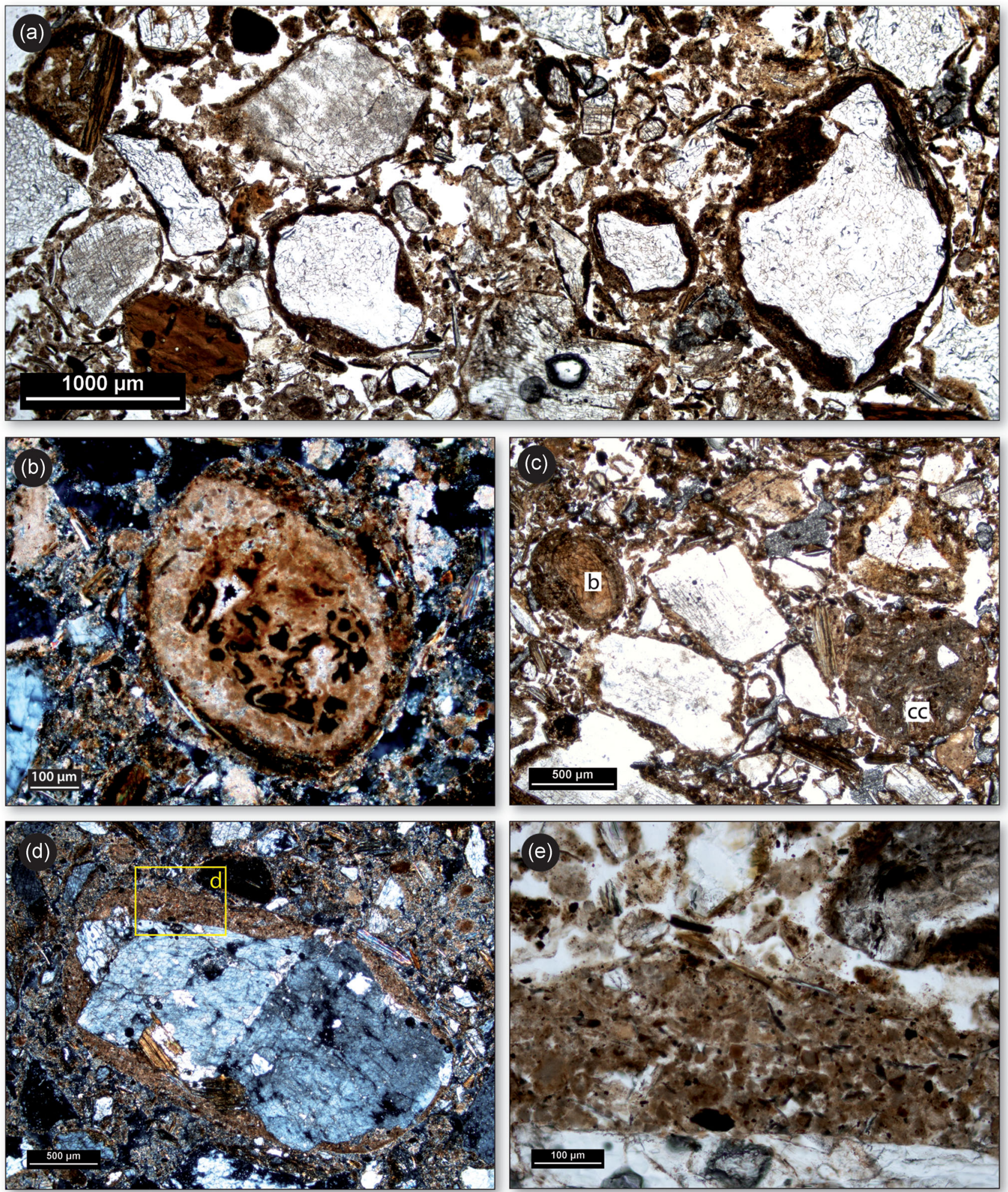

FIGURE 9 Colluvial features over human-induced soil erosion. (a) Area of concentration of the well-rounded coatings microfabric (PPL; scales: $1 \mathrm{~mm}$ ), note their composition predominantly of charred organic matter. (b) Example of ashes affected by colluvial processes: a wellrounded ash aggregate is coated by organic fine material; note the possibly manganese impregnations, indicative of redox processes before reworking (dark areas) (XPL; scale: $100 \mu \mathrm{m}$ ). (c) Example of bone (b) exhibiting a thick rounded coating and a well-rounded carbonate-cemented aggregate (cc) after undergoing post-cementation transport. (d) Grain of granite with a well-rounded coating of fine material, manly calcitic granules, probably ashes (XPL; scale: $500 \mu \mathrm{m}$ ). (e) Detail of the ash coating in the rectangle marked in (b), where the ash rhombs can be seen (PPL; scale: $100 \mu \mathrm{m})$. PPL, plane-polarized light; XPL, crossed-polarized light [Color figure can be viewed at wileyonlinelibrary.com] 
zooarchaeological evidence of toad (Carvalho et al., 2017), indicates the first phase of saturation of the deposit in vadose water, once sediment accumulation ceased.

Another aspect important to consider in the environment reconstruction that arises from the sedimentation process in the rockshelter is that today there are no higher points on the granitic platform than the tor itself. In fact, the Neolithic deposit is on top of a slope incised by a seasonal rill that borders the monumental tor to the south (Figure 10). However, the platform where the tor and the rockshelter are located is inserted into a broader stepped slope that is the most likely a catchment for sediments. The seasonal rill and the south slope seen today would prevent the sediments coming downslope from the south to accumulate in the rockshelter. This allows us to infer a post-Neolithic incision of the south slope (Figure 10).

\section{5 | Anthropogenic activities}

The presence of ash, burnt bone and charcoal points to anthropogenic combustion activity. The stone structure found in layer 11 appears to be evidence for combustion activity on the site (Carvalho et al., 2017). Ashes are widely observed to cover layer 11; however, the generalized distribution of secondary calcite precipitates allows us to infer that ashes were dispersed in the upper layers as well, before dissolution. In layer 11, aggregates composed of cemented ash and calcined plant tissue (Figure 4d,e) reveals that ashes from combustion in the rockshelter were locally reworked by trampling or bioturbation during the reoccupations of the site.

Microcharcoal and charred fine organic matter are dominant in the whole deposit, being the main constituents of the rounded coatings (Figure 9a). In layer 11, ashes also occur as well-rounded aggregates and grain coatings (Figure 9b-e). This seems to indicate that the colluvial sediments that filled the rockshelter were already rich in pyrogenic material. The rounded coatings of ash, organic and silty material around lithological grains and archaeological components (Figure 9a-e), suggest that these materials were also affected by the colluvial processes in the slope that transported the sediments into the rockshelter.

One possible cause for the presence of pyrogenic fine material in the immediately surrounding area of Penedo dos Mouros is fires, perhaps undertaken by the Neolithic herders for vegetation clearance. This could correspond to the first period of "human-induced expansion of steppe grasses" in the lowlands around Serra da Estrela, inferred from the study of the pollen sequence from Charco da Candieira Lake in the mountain's central plateau (Van der Knaap \& van Leeuwen, 1995 , p. 186). However, the starting date for this period in question is c. 7,500 cal B.C., which precedes any Neolithic evidence in the region, as mentioned previously. The pollen record around $4,500 \mathrm{cal}$ B.C., which corresponds to the Early to Middle Neolithic transition, indicates the lake level and size had been influenced by major human activity on the mountain itself (Van der Knaap \& van Leeuwen, 1995). The dating obtained from the pollen sequence should be revised to establish a more precise temporal correlation with Penedo dos Mouros.

Kaal et al. (2011) documented an episode of forest degradation in Galicia (NW Iberia) starting at c. 4,000 cal B.C., which points to the use of fire by humans to clear the land to create space for grazing, based on combined studies of macro- and micro-charcoal, and pollen from several soil samples. As further studies suggest, clearance by fire increase the rate of soil erosion (e.g., Knicker, 2011; Macphail \& Goldberg, 2017; Schmid, Skjemstad, Glaser, Knicker, \& Kögel-Knabner, 2002; Van VlietLanoë, Helluin, Pellerin, \& Valadas, 1992), which must have played a major role in the sedimentation of Penedo dos Mouros.

Colluvial deposits associated with clearance have been found to contain microfeatures similar with those observed at Penedo dos Mouros, such as high concentrations of large and micro-charcoal, ash and charcoal-rich soil fragments (Deák, Gebhardt, Lewis, Usai, \& Lee, 2017, Macphail \& Goldberg, 2017). Furthermore, podzolization after clearance has been documented, caused by an enrichment in charcoal (Gebhardt, 1993; Macphail, Courty, \& Gebhardt, 1990). Mobilization of colloidal clay has also been associated with well-drained soils in extremely acidic environments, leading to the accumulation of limpid clay coatings as a consequence of addition of materials that cause alkalinization, such as ash (Deák et al., 2017). At Penedo dos Mouros, despite the general lack of clay, limpid clay coating of colloidal nature formed probably derived from the decay and hyper saturation of the organic matter within the deposit, which was anthropogenically induced. The formation of the aluminium-manganese hardpan with spodic characteristics at Penedo dos Mouros appears to be related to meteoric water saturation of the deposit, after sedimentation.

For these reasons, there is a possibility that the deposit of Penedo dos Mouros bears evidence of local vegetation clearance linked to the short, seasonal visits of the Neolithic occupants of the site. The absence of microscopic components indicative of animal stabling (abundant phytoliths or burnt herbivore dung and associated silica spherulites), or features like planar porosity or micro-bedding derived from compaction (Angelucci, Boschian, Fontanals, Pedrotti, \& Vergès, 2009; Courty, Macphail, \& Wattez, 1991; Égüez, Mallol, Martín-Socas, \& Camalich, 2014; Shahack-Gross, 2017), lead us to exclude stabling as a past use of the rockshelter, which was already anticipated by the limited area. Focusing on the local topographic features and the relatively poor soils on the slope, such clearance would possibly be intended for the creation of grazing land. This evidence agrees with the artefactual assemblage: rare small-sized pottery vessels, expedient knapping procedures of local raw materials (quartz), and curated strategies on the management of nonlocal knapping stones (flint) associated with short-term occupations (Carvalho et al., 2017), perhaps related to the first signs of caprine pastoralism practices in the region.

\section{5 | CONCLUSION}

The micromorphological approach to the Neolithic deposit of Penedo dos Mouros allowed us to reconstruct the sequence of depositional 
FIGURE 10 Slope processes in Penedo ds Mouros. (a) Schematic representation of the slope of the Boco Valley, where Penedo dos Mouros is located, adapted from Angelucci et al. (2004), not to scale. Note that the difference between the line of incision of the subsidiary valleys and the slope profile should post-date the Neolithic occupations. (b) General view of Penedo dos Mouro from South, the rockshelter (Rs) is on top of SE slope draining to the seasonal rill [Color figure can be viewed at wileyonlinelibrary.com]
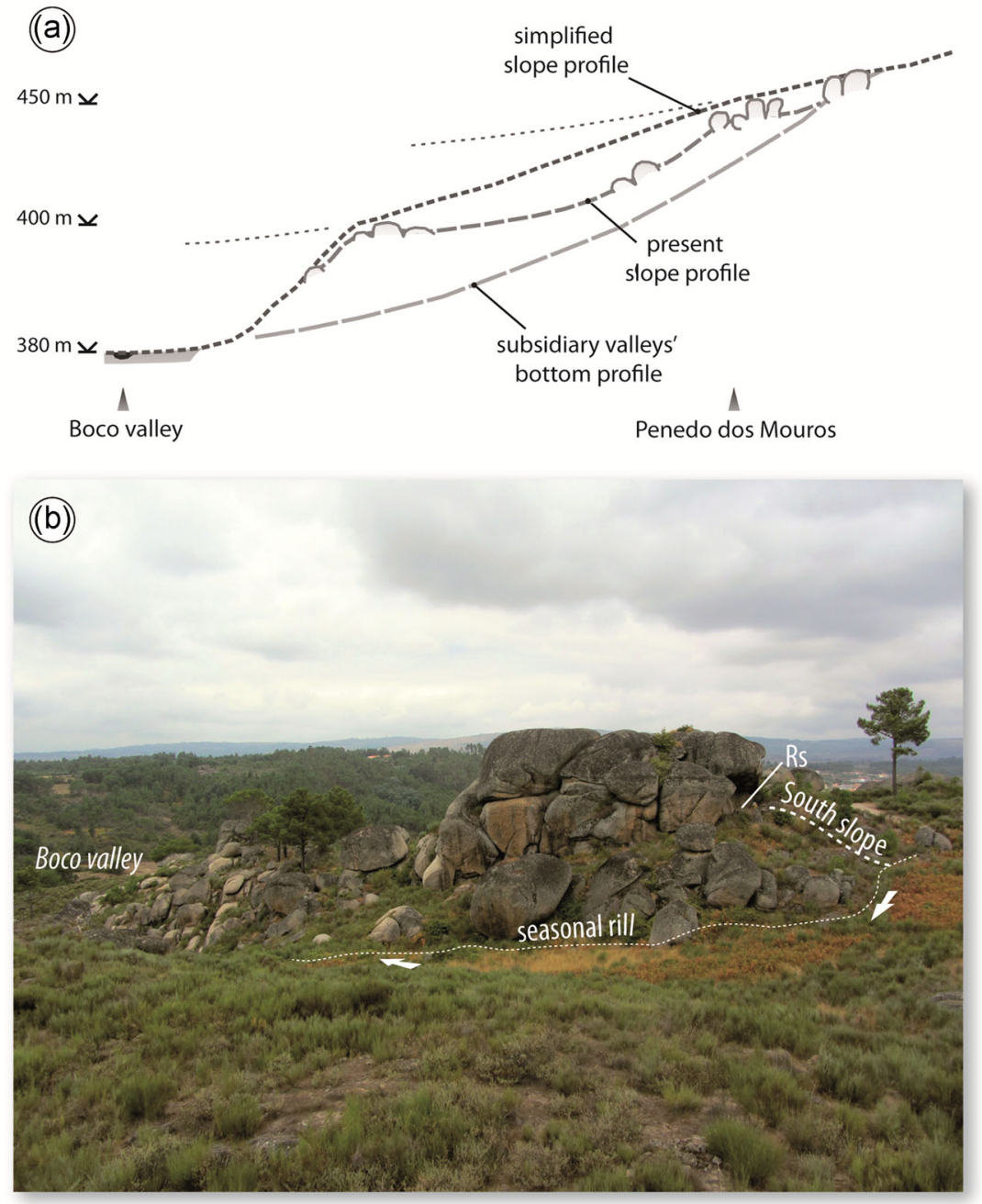

and post-depositional processes involved in the site formation, answering specific questions about the site contextual integrity and raising new aspects that have implications for the archaeological and palaeoenvironmental evidence.

This geoarchaeological investigation confirms that the surface of the Neolithic deposit of the Penedo dos Mouros Rockshelter was exposed to weathering agents responsible for pedogenetic processes, before being sealed by the medieval embankment. Therefore, the anthropogenic inputs, such as bone, most probably correspond to the Neolithic occupation of the rockshelter, and an explanation for the radiocarbon result more recent than expected date (Carvalho et al., 2017), might to be due to the diagenetic alteration of the bones at the deposit, whose advanced state of remineralization was observed in thin section.

Micromorphological analysis provided an explanation for the preservation of organic material in the Neolithic deposit. The granitic sand was cemented by calcium carbonate, most likely derived from ashes since there are no other sources of calcium. The very coarse grain size and hardness of the deposit made it impossible for dispersed ashes to be identified during excavation in the field; however, they were visible microscopically. After cementation, the deposit continued to undergo saturation from vadose water, which led to the decay of the high amounts of anthropogenically induced fine organic matter. After decay, this material percolated and accumulated in the form of an aluminium-manganese hardpan of colloidal nature across the previously carbonate-cemented layer. Ashes and pyrogenic organic matter may have been produced and dispersed across the site, but the sediment groundmass and texture suggest that these components could also be transported along with geogenic materials, from erosion of surrounding soils, and affected by colluviation. This aspect might be linked to clearance fires during the occupation of the rockshelter in the Neolithic.

The microscopic study highlights that archaeological record has great potential to preserve, at the microscale, valuable clues regarding broader aspects, such as Mid-Holocene local environmental conditions and landscape evolution, by reflecting variability in hydrological regime and a possible coeval incision of the valley contiguous to the site. The microarchaeological investigation conducted on the Neolithic deposit of Penedo dos Mouros shows that this is a valuable approach for the correct contextualization of archaeological 
remains and human activities in Neolithic contexts where there is an apparent lack of a clear anthropogenic stratification. This study reflects the need for high-resolution studies of the region's environmental record, since it is evident that there were active processes during the Holocene in the region that must be considered when making paleolandscape reconstructions, especially when correlating them with prehistoric socioeconomic interpretations.

\section{ACKOWLEDGEMENTS}

The excavations at Penedo dos Mouros were carried out in the framework of the research project "The Upper Mondego Valley: land of frontier between Christians and Muslims" directed by CT, which was funded by the Portuguese Foundation for Science and Technology for the 2007-2010 triennium. Vera Aldeias, Eneko Iriarte, Susan Mentzer, Christopher Miller and Roz Gillis provided valuable insights and comments on earlier versions of this article. Special thanks to Richard Macphail for his help in the SEM-EDS analysis. We are also grateful to the anonymous reviewers and editor who helped improve the manuscript.

\section{DATA AVAILABILITY STATEMENT}

All data that support the findings of this study are contained in the article.

\section{ORCID}

Carlos D. Simões (iD http://orcid.org/0000-0002-4570-1308

António F. Carvalho (D) http://orcid.org/0000-0002-0912-2325 Catarina Tente (D) http://orcid.org/0000-0002-7944-1583

\section{REFERENCES}

Angelucci, D. E., Tente, C., \& Martins, A. R. (2004). O Penedo dos Mouros (Gouveia) no seu contexto paisagístico: Anotações preliminares. Revista portuguesa de arqueologia, 7, 467-481.

Angelucci, D. E., Boschian, G., Fontanals, M., Pedrotti, A., \& Vergès, J. M. (2009). Shepherds and karst: The use of caves and rock-shelters in the Mediterranean region during the Neolithic. World Archaeology, 41, 191-214.

Arpin, T. L., Mallol, C., \& Goldberg, P. (2002). Short contribution: A new method of analyzing and documenting micromorphological thin sections using flatbed scanners: Applications in geoarchaeological studies. Geoarchaeology, 17, 305-313.

Berna, F., Matthews, A., \& Weiner, S. (2004). Solubilities of bone mineral from archaeological sites: The recrystallization window. Journal of Archaeological Science, 31, 867-882.

Bertran, P., \& Texier, J. -P. (1999). Facies and microfacies of slope deposits. Catena, 35, 99-121.

Bronk Ramsey, C. (2013). OxCal 4.2. Web Interface Build, 78.

Buurman, P., \& Jongmans, A. G. (2005). Podzolisation and soil organic matter dynamics. Geoderma, 125, 71-83.

Canti, M. G. (2003). Aspects of the chemical and microscopic characteristics of plant ashes found in archaeological soils. Catena, 54, 339-361.

Canti, M. G., \& Brochier, J. E. (2017b). Plant ash. In C. Nicosia \& G. Stoops (Eds.), Archaeological Soil and SedimentMicromorphology (pp. 147-154). Chichester: John Wiley \& Sons, Ltd.

Cardoso, J. L., \& González, A. (2002). Testemunhos da ocupação préhistórica da Serra da Estrela. Al-Madan, 11, 242.

Carvalho, A. F. (2012). Portugal. In M. Rojo, R. Garrido \& Í. García (Eds.), El Neolítico en la Península Ibérica y su contexto europeo (pp. 175-212). Madrid: Cátedra.
Carvalho, A. F. (2018). When the Mediterranean met the Atlantic. A socioeconomic view on Early Neolithic communities in central-southern Portugal. Quaternary International, 470, 472-484.

Carvalho, A. F., Pereira, V., Duarte, C., \& Tente, C. (2017). Neolithic archaeology at the Penedo dos Mouros rock-shelter (Gouveia, Portugal) and the issue of primitive transhumance practices in the Estrela Mountain range. Zephyrus, 79, 19-38.

Costa, F. A. P. (1868). Noções sobre o estado prehistórico da Terra e do Homem seguidas da descripção de alguns dolmins ou antas de Portugal. Lisbon: Academia Real das Sciencias.

Courty, M. A., \& Fedoroff, N. (2002). Micromorphologie des sols et sédiments archéologiques. Géologie de la Préhistoire, 511-554.

Courty, M. A., Goldberg, P., \& Macphail, R. (1989). Soils and micromorphology in archaeology. Cambridge: Cambridge University Press.

Courty, M. A., Macphail, R. I., \& Wattez, J. (1991). Soil micromorphological indicators of pastoralism: With special reference to Arene Candide, Finale Ligure, Italy. Rivista di Studi Liguri, 57, 127-150.

Deák, J., Gebhardt, A., Lewis, H., Usai, M. R., \& Lee, H. (2017). Soils disturbed by vegetation clearance and tillage. In C. Nicosia \& G. Stoops (Eds.), Archaeological soil and sediment micromorphology (pp. 233-259). Chichester: John Wiley \& Sons, Ltd.

Durand, N., Monger, H. C., \& Canti, M. G. (2010). 9-Calcium carbonate features. In G. Stoops, V. Marcelino \& F. Mees (Eds.) Interpretation of micromorphological features of soils and regoliths. Amsterdam: Elsevier.

Égüez, N., Mallol, C., Martín-Socas, D., \& Camalich, M. D. (2014). Radiometric dates and micromorphological evidence for synchronous domestic activity and sheep penning in a Neolithic cave: Cueva de El Toro (Málaga, Antequera, Spain). Archaeological and Anthropological Sciences, 8, 107-123.

Fernández-Mier, M., \& Tente, C. (2018). Transhumant herding systems in Iberia. In E. Costello \& E. Svensson (Eds.), Historical archaeologies of transhumance across Europe (pp. 119-132). London: Routledge.

Gebhardt, A. (1993). Micromorphological evidence of soil deterioration since the mid-Holocene at archaeological sites in Brittany, France. The Holocene, 3, 333-341.

Goldberg, P., \& Arpin, T. L. (1999). Micromorphological analysis of sediments from Meadowcroft Rockshelter, Pennsylvania: Implications for radiocarbon dating, Journal of Field Archaeology (26, pp. 325-342).

Goldberg, P., \& Berna, F. (2010). Micromorphology and context. Quaternary International, 214, 56-62.

Kaal, J., Marco, Y. C., Asouti, E., Seijo, M. M., Cortizas, A. M., Casáis, M. C., \& Boado, F. C. (2011). Long-term deforestation in NW Spain: linking the Holocene fire history to vegetation change and human activities. Quaternary Science Reviews, 30(1-2), 161-175.

Karkanas, P. (2010). Preservation of anthropogenic materials under different geochemical processes: A mineralogical approach. Quaternary International, 214, 63-69.

Knicker, H. (2011). Pyrogenic organic matter in soil: Its origin and occurrence, its chemistry and survival in soil environments. Quaternary International, 243, 251-263.

Kristiansen, S. M. (2001). Present-day soil distribution explained by prehistoric land-use: Podzol-Arenosol variation in an ancient woodland in Denmark. Geoderma, 103, 273-289.

Macphail, R. I. (1989). Paleosols in archaeology: Their role in understanding Flandrian pedogenesis. In P. Wright (Ed.), Paleosols: Their recognition and interpretation. Oxford: Blackwell Scientific Publications.

Macphail, R. I., Courty, M. A., \& Gebhardt, A. (1990). Soil micromorphological evidence of early agriculture in north-west Europe. World Archaeology, 22, 53-69.

Macphail, R. I., \& Goldberg, P. (2017). Applied soils and micromorphology in archaeology. Cambridge: Cambridge University Press. 
Mallol, C., Cabanes, D., \& Baena, J. (2010). Microstratigraphy and diagenesis at the upper Pleistocene site of Esquilleu Cave (Cantabria, Spain). Quaternary International, 214, 70-81.

Mallol, C., \& Mentzer, S. M. (2017). Contacts under the lens: Perspectives on the role of microstratigraphy in archaeological research. Archaeological and Anthropological Sciences, 9, 1645-1669.

Mentzer, S. M. (2014). Microarchaeological approaches to the identification and interpretation of combustion features in prehistoric archaeological sites. Journal of Archaeological Method and Theory, 21, 616-668.

Mikkelsen, J. H., Langohr, R., \& Macphail, R. I. (2007). Soilscape and landuse evolution related to drift sand movements since the Bronze Age in Eastern Jutland, Denmark. Geoarchaeology, 22, 155-179.

Mücher, H.J. (1974). Micromorphology of slope deposits: the necessity of a classification. In Rutherford, G. K. (Ed.), Soil Microscopy (pp. 553-566). Kingston, Ontario: The Limestone Press.

Mücher, H., Steijn, H. V., \& Kwaad, F. (2010). Colluvial and mass wasting deposits. In G. Stoops, V. Marcelino \& F. Mees (Eds.), Interpretation of micromorphological features of soils and regoliths. Amsterdam: Elsevier.

Nicosia, C., \& Stoops, G. (2017). Archaeological soil and sediment micromorphology, Chichester: John Wiley \& Sons, Ldt.

Reimer, P. J., Bard, E., \& Bayliss, A. (2013). IntCal13 and Marine13 radiocarbon age calibration curves $0-50,000$ years cal BP. Radiocarbon, 55(4), 1869-1887.

Ribeiro, O. (1941). Contribuição para o estudo do pastoreio na Serra da Estrêla. Revista da Faculdade de Letras de Lisboa, IV, 1-2, 213-303.

Sarmento, M. (1983). Expedição scientifica à Serra da Estrella em 1881, Secção de Archeologia. Lisbon: Sociedade de Geographia de Lisboa.

Schmid, E. M., Skjemstad, J. O., Glaser, B., Knicker, H., \& Kögel-Knabner, I. (2002). Detection of charred organic matter in soils from a Neolithic settlement in Southern Bavaria, Germany. Geoderma, 107, 71-91.

Senna-Martinez, J. C., \& Ventura, J. M. (2008). Neolitização e Megalitismo na plataforma do Mondego: Algumas reflexões sobre a transição Neolítico antigo/Neolítico médio, IV Congreso del Neolítico Peninsular (II, pp. 77-84). Alicante: Museo Arqueológico de Alicante.

Sequeira Braga, M. A., Paquet, H., \& Begonha, A. (2002). Weathering of granites in a temperate climate (NW Portugal): Granitic saprolites and arenization. Catena, 49, 41-56.

Shahack-Gross, R. (2017). Animal gathering enclosures. In C. Nicosia \& G. Stoops (Eds.), Archaeological soil and sediment micromorphology (pp. 265-280). Chichester: John Wiley \& Sons, Ltd.

Shahack-Gross, R., Berna, F., Karkanas, P., Lemorini, C., Gopher, A., \& Barkai, R. (2014). Evidence for the repeated use of a central hearth at Middle Pleistocene (300Â ky ago) Qesem Cave, Israel. Journal of Archaeological Science, 44, 12-21.

Stoops, G. (2003). Guidelines for analysis and description of soil and regolith thin sections. Madison, WI: Soil Science Society of America Inc.

Stoops, G., Marcelino, V., \& Mees, F. (2010). 2-Micromorphological features and their relation to processes and classification: General guidelines and keys, Interpretation of Micromorphological Features of Soils and Regoliths. Amsterdam: Elsevier.

Taboada, T., \& Garcia, C. (1999). Smectite formation produced by weathering in a coarse granite saprolite in Galicia (NW Spain). Catena, 35, 281-290.
Tente, C. (2007). Comunidades medievais cristãs do Alto Mondego: Projecto de estudo das estratégias de ocupação do território. Promontoria, 5, 245-269.

Tente, C. (2010). Arqueologia medieval cristã no Alto Mondego. Ocupação e exploração do território nos séculos $\mathrm{V}$ a XI. Lisbon: Universidade Nova de Lisboa.

Tente, C. (2012/2013). A origem da formação da paisagem rural medieval no Alto Mondego (Guarda, Portugal). O contributo da arqueologia. Norba. Revista de História, 25-26, 61-75.

Valente, M. J., \& Carvalho, A. F. (2014). Zooarchaeology in the Neolithic and Chalcolithic of Southern Portugal. Environmental Archaeology. 19(3), 226-240.

Valera, A. C. (2005). Problemas da neolitização na bacia interior do Mondego, III Congreso del Neolítico en la Península Ibérica (pp. 945-956). Santander: Universidad de Cantabria.

Van den Brink, L., \& Janssen, C. (1985). The effect of human activities during cultural phases on the development of montane vegetation in the Serra de Estrela, Portugal. Review of Palaeobotany and Palynology, 44, 193-215.

Van der Knaap, W. O., \& van Leeuwen, J. F. N. (1995). Holocene vegetation succession and degradation as responses to climatic change and human activity in the Serra de Estrela, Portugal. Review of Palaeobotany and Palynology, 89, 153-211.

Van der Knaap, W. O., \& van Leeuwen, J. F. N. (1997). Late Glacial and early Holocene vegetation succession, altitudinal vegetation zonation, and climatic change in the Serra da Estrela, Portugal. Review of Palaeobotany and Palynology, 97, 239-285.

Van Vliet-Lanoë, B., Helluin, M., Pellerin, J., \& Valadas, B. (1992). Soil erosion in Western Europe: From the last interglacial to the present, Past and Present Soil Erosion: Archaeological and geographical perspectives (pp. 101-114). Oxford: Oxbow.

Villagrán, X. 2012. Micromorfologia de sítios concheiros da América do Sul: arqueoestratigrafia e processos de formação de sambaquis (Santa Catarina, Brasil) e conheros (Terra do Fogo, Argentina) (unpublished Ph.D. dissertation). São Paulo: Universidade de São Paulo.

Weiner, S. (2010). Microarchaeology: Beyond the visible archaeological record. New York: Cambridge University Press.

Wilson, C. A. (2017). Electron probe X-ray micro analysis (SEM-EPMA) techniques. In C. Nicosia \& G. Stoops (Eds.), Archaeological soil and sediment micromorphology (pp. 451--459). Chichester: John Wiley \& Sons, Ltd.

Wilson, M. A., \& Righi, D. (2010). 12-Spodic materials. In G. Stoops, V. Marcelino \& F. Mees (Eds.), Interpretation of micromorphological features of soils and regoliths. Amsterdam: Elsevier.

How to cite this article: Simões CD, Carvalho AF, Tente C. Neolithic geoarchaeology at Penedo dos Mouros Rockshelter: Mid-Holocene site formation, diagenesis and human activity at the foothills of Serra da Estrela (Portugal). Geoarchaeology. 2020;1-19. https://doi.org/10.1002/gea.21785 